\title{
Plant Nitric Oxide Signaling under Drought Stress
}

\author{
Su-Ee Lau ${ }^{1,2}\left(\right.$, Mohd Fadhli Hamdan ${ }^{3}$, Teen-Lee Pua ${ }^{1}$, Noor Baity Saidi ${ }^{2}\left(\mathbb{D}\right.$ and Boon Chin Tan ${ }^{1, *}$ (1) \\ 1 Centre for Research in Biotechnology for Agriculture, University of Malaya, Kuala Lumpur 50603, Malaysia; \\ suee@um.edu.my (S.-E.L.); teenleepua@um.edu.my (T.-L.P.) \\ 2 Department of Cell and Molecular Biology, Faculty of Biotechnology and Biomolecular Sciences, \\ Universiti Putra Malaysia, Serdang 43400, Malaysia; norbaity@upm.edu.my \\ 3 School of Biological Sciences, The University of Hong Kong, Pokfulam Road, Hong Kong, China; \\ fadhli@hku.hk \\ * Correspondence: boonchin@um.edu.my; Tel.: +603-79677982
}

Citation: Lau, S.-E.; Hamdan, M.F.; Pua, T.-L.; Saidi, N.B.; Tan, B.C. Plant Nitric Oxide Signaling under Drought Stress. Plants 2021, 10, 360. https://doi.org/10.3390/ plants10020360

Academic Editor: Gábor Feigl

Received: 30 December 2020

Accepted: 10 February 2021

Published: 13 February 2021

Publisher's Note: MDPI stays neutral with regard to jurisdictional claims in published maps and institutional affiliations.

Copyright: (c) 2021 by the authors. Licensee MDPI, Basel, Switzerland. This article is an open access article distributed under the terms and conditions of the Creative Commons Attribution (CC BY) license (https:/ / creativecommons.org/licenses/by/ $4.0 /)$.

\begin{abstract}
Water deficit caused by drought is a significant threat to crop growth and production. Nitric oxide (NO), a water- and lipid-soluble free radical, plays an important role in cytoprotection. Apart from a few studies supporting the role of NO in drought responses, little is known about this pivotal molecular amendment in the regulation of abiotic stress signaling. In this review, we highlight the knowledge gaps in NO roles under drought stress and the technical challenges underlying NO detection and measurements, and we provide recommendations regarding potential avenues for future investigation. The modulation of NO production to alleviate abiotic stress disturbances in higher plants highlights the potential of genetic manipulation to influence NO metabolism as a tool with which plant fitness can be improved under adverse growth conditions.
\end{abstract}

Keywords: Abiotic stress; crop improvement; drought; nitric oxide; S-nitrosylation; signaling molecule; water deficit

\section{Introduction}

The loss of millions of hectares of arable lands to various stresses every year continues to impose a major threat to agriculture. Almost $90 \%$ of all arable lands have been exposed to major environmental stresses, such as salinity, drought, extreme temperature, heavy metals, and ultraviolet radiation [1]. Of these, water deficit caused by drought is amongst the main threats to crop growth and production worldwide. In the US alone, the combined effect of drought and increased temperature has caused a total loss of about USD555 billion for the past 10 years (2010-2019) in agricultural production [2]. The effect of drought is even more devastating in developing countries whose economies largely rely on their agricultural output. According to the Food and Agriculture Organization of the United Nations (FAO), 30\% of agricultural losses (USD $\sim 29$ billion) due to drought was recorded in developing countries in the period of 2005-2015 [3].

Drought conditions cause a disruption to the cellular redox homeostasis in plants, leading to oxidative stress and cell injury [4]. Plants respond and adapt to drought stress by changing their morphology, biochemistry, physiology, and molecular mechanisms [5]. One of the major signaling molecules present in the cascade of this stress adaptation response is nitric oxide (NO), a water- and lipid-soluble free radical and a gaseous, redox-related signaling molecule that is rapidly produced by multiple hormonal and environmental stimuli [6]. NO regulates and maintains the level of reactive oxygen species (ROS) by inducing transcriptional changes of various targets involved in plant defense and cell death, translocation, signal transduction, and ROS metabolism [7].

Some studies have supported the roles of NO in drought adaptation, but little is known about this important molecular amendment in modulating signaling in abiotic stresses. Studies regarding the origin and production of NO during water deficit, its sensing, and transduction as well as its physiological and molecular processes for the 
amelioration of drought stress remain scarce. Continued efforts in examining the roles of NO during plant adaptation to drought stress and its detection and measurement methods are, therefore, crucial for facilitating breeding and crop improvement programs to counter the challenges faced by the agricultural industry. In this review, we provide an overview of $\mathrm{NO}$ biosynthesis and its roles and regulatory mechanisms in response to drought stress. We also highlight the technical challenges of NO detection and measurements and suggest potential avenues for future investigation.

\section{Nitric Oxide: Background}

\subsection{Source and Biosynthesis of NO in Plants}

NO biosynthesis has been well characterized in mammals. It is mainly synthesized through NO synthase (NOS) activity [8]. In plants, NO can be biosynthesized via reductive and oxidative routes [9]. The most thoroughly researched NO biosynthetic pathway in plants is the reduction of nitrite, either enzymatically or nonenzymatically. Enzymes that have been demonstrated to catalyze the generation of NO from nitrites are nitrate reductase (NR) [10], the membrane-bound nitrite NO reductase (NiNOR) [11], and peroxisomal xanthine oxidoreductase (XOR) [12]; mitochondrial electron transfer chain-dependent enzymatic nitrite reduction has also been reported to be capable of this [13]. In contrast, nonenzymatic reduction has been reported to occur in the apoplast of barley aleurone layers under acidic environments with the presence of high concentrations of nitrate $\left(\mathrm{NO}_{2}{ }^{-}\right)$[14] The oxidative route of NO production relies on the oxidation of aminated molecules, such as L-arginine(L-Arg) by the L-Arg-dependent NOS-like enzyme [15], polyamines [16], and hydroxylamine [17]. The routes of NO biosynthesis are illustrated in Figure 1.

\subsection{NO Donors}

Synthetic NO donors are active substances that release NO. They have been widely used as experimental tools to explore the roles of endogenous NO in plant adaptation to abiotic and biotic stresses. Examples of NO donors are sodium nitroprusside (SNP), Snitro-N-acetylpenicillamine (SNAP), 3-morpholinosydnonimine (SIN-1), S-nitroglutathione (GSNO), NONOates, and organic $\mathrm{NO}_{3}{ }^{-}$(Figure 2) [18]. Among the three most used $\mathrm{NO}$ donors, namely SNAP, GSNO, and SNP, the NO generation rate is the highest in SNAP, followed by GSNO and SNP. In contrast, SNP has the longest half-life in the solution (12 h) compared to GSNO $(7 \mathrm{~h})$ and SNAP $(3 \mathrm{~h})$. In terms of photosensitivity, SNP is much higher when compared with GSNO and SNAP [19]. Among these NO donors, SNP is widely used in plant research because of its stability and its stability to act as a long-lasting NO reservoir [13].

NO donors are either supplemented to the roots in growth media or through fertigation [20], which is sprayed onto the plants' leaves [21] with the aid of nanoparticles [22,23], or through a seed-priming agent $[24,25]$. The mechanisms of action of NO are yet to be fully revealed as it is highly dependent on various factors, such as plant species, age, size, source, concentration of NO donor, treatment duration, and methods of application [26]. For instance, application of $0.2 \mathrm{mmol} / \mathrm{L} \mathrm{SNP}$ alleviated drought tolerance in wheat seedlings, whereas a concentration of SNP that was 10 times higher led to excessive generation of ROS and low antioxidant activities [27]. This observation was in agreement with the study by Cao et al. [11], where root oxidative damage caused by water stress was successfully alleviated by a lower concentration of SNP (less than $20 \mu \mathrm{mol} / \mathrm{L}$ ), whereas a higher concentration of SNP (more than $40 \mu \mathrm{mol} / \mathrm{L} \mathrm{SNP)} \mathrm{affected} \mathrm{the} \mathrm{root} \mathrm{growth,} \mathrm{suggesting} \mathrm{that}$ high NO contents might be toxic to plants and cause cellular damage. 


\section{NO biosynthesis routes}

\section{Reductive \\ Oxidative}

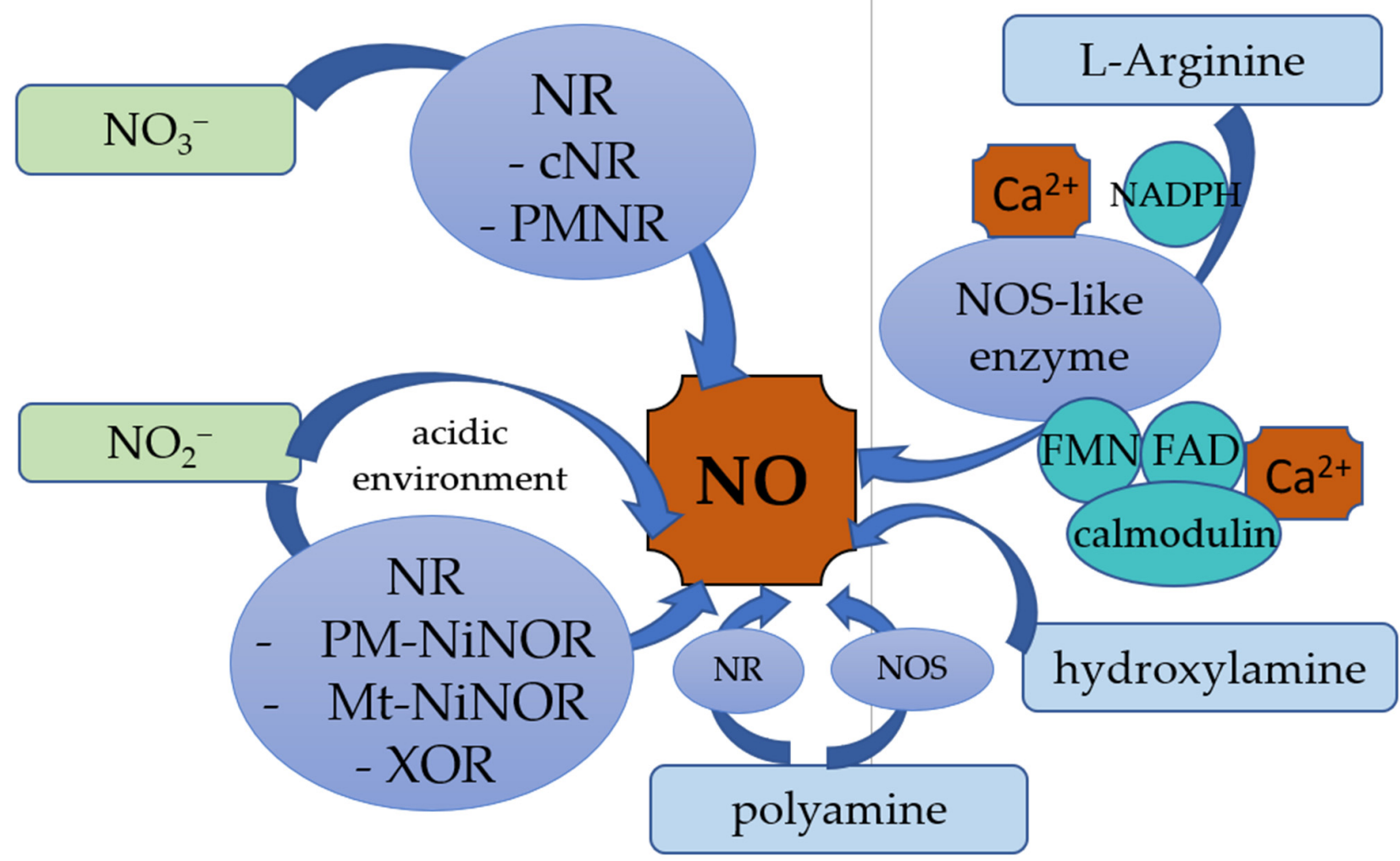

Figure 1. Schematic diagram showing the major routes of nitric oxide (NO) biosynthesis. NO synthesis occurs through (I) reductive mechanism or (II) oxidative mechanism. (I) NO reductive mechanism mostly occurs in plasma membrane, chloroplasts, apoplast, peroxisomes, cytoplasm, and mitochondria through reduction of nitrate $\left(\mathrm{NO}_{3}{ }^{-}\right)$or nitrite $\left(\mathrm{NO}_{2}{ }^{-}\right)$ by nitrate reductase (NR). NO production through nitrate substrate is reduced by cytosolic nitrate reductase (cNR) and plasma membrane-bound nitrate reductase (PMNR), whereas NO production through nitrite substrate is reduced by plasma membrane-bound nitrite: NO reductase (PM-NiNOR), mitochondrial electron transfer chain-dependent enzymatic nitrite: NO reductase (Mt-NiNOR), XOR. In an acidic environment, nitrite produces NO through several reversible reactions. Polyamines induce NO production through reductive and oxidative mechanisms. (II) The oxidation of L-Arg takes place in chloroplasts and leaf peroxisomes. In chloroplasts, the oxidation of L-Arg requires nicotinamide adenine dinucleotide phosphate (NADPH) and calcium ions $\left(\mathrm{Ca}^{2+}\right)$, whereas in leaf peroxisomes, the oxidation of L-Arg requires flavin mononucleotide (FMN), flavin adenine dinucleotide (FAD), calmodulin, and $\mathrm{Ca}^{2+}$. Hydroxylamine acts as a substrate in the oxidative mechanism; however, its pathway in NO production remains unclear. NOS, NO synthase. 
(a)<smiles>CC(=O)N[C@@H](C(=O)O)C(C)(C)SN=O</smiles>

(b)

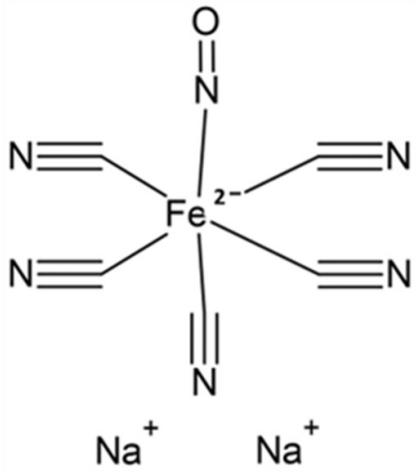

(c)<smiles>[NH-]c1cn[n+](N2CCOCC2)o1</smiles>

(d)<smiles>CCN(CC)C([OH2+])N=O</smiles>

(e)<smiles>N[C@@H](CCC(=O)N[C@@H](CSN=O)C(=O)NCC(=O)O)C(=O)O</smiles>

Figure 2. Chemical structures of nitric oxide (NO) donors. (a) S-nitro-N-acetylpenicillamine (SNAP), (b) sodium nitroprusside (SNP), (c) 3-morpholinosydnonimine (SIN-1), (d) NONOates, and (e) S-nitroglutathione (GSNO).

\subsection{Functions of $\mathrm{NO}$ in Plants}

NO was initially considered as an air pollutant. This molecule has also been reported to pose an inhibitory effect on plant growth by fragmenting DNA and damaging membranes [28], reducing the photosynthesis level in oat and alfalfa [29], and lowering respiration in carrot cell suspensions [30]. From simply an air pollutant, NO has now become a vital redox signaling molecule.

$\mathrm{NO}$ and its derived molecules (reactive nitrogen species, RNS) are ubiquitous in plants. Other RNSs include peroxynitrite (ONOO-), S-nitrosoglutathione (GSNO), and S-nitrosothiols (SNOs). NO and RNS are involved in various developmental and physiological processes, such as seed germination and dormancy [31], shoot and root growth [32], flowering [33], fruit ripening [34], yield [35], stomatal closure [36], formation of guard cells [37], senescence [38], photosynthesis regulation [39], mitochondria functionality [30], gravitropism [40] and pollen tube growth [41]. The way by which NO and RNS exert their function is still largely unknown. It was shown that NO exerts part of its effects through post-translational modifications (PTMs), such as tyrosine nitration, S-nitrosylation, and metal nitrosylation. The details of plant proteins modified by NO at the post-translational level will be discussed in Section 4 .

It is now recognized that $\mathrm{NO}$ protects against damage provoked by oxidative stress due to biotic [42,43] and abiotic stresses [44]. ROS can be produced under both normal and stressed conditions. However, plants produce more ROS accumulation under stress conditions [45]. NO may act as a detoxifier of ROS by minimizing its harmful effect towards plants [46]. This phenomenon was observed in plants challenged with metal toxicity [47], high temperature [48], salinity [49], and chilling stress [50]. The roles of NO in alleviating drought stress will be described in Section 3. 


\section{NO and Drought Stress}

\subsection{Impacts of Drought on Plants}

Drought stress adversely impacts plant growth and development at physiological, biochemical, and molecular levels. It disturbs the appearance of plants by causing chlorosis and necrosis signs [21]; prolongs the duration of primordia initiation; and reduces the number of shoots per explant, shoot length, leaf number, leaf area [51], fruit yield, and plant biomass [26]. Besides the aboveground plant parts, underground parts like roots also respond to drought by changing their root length to become either shorter [52] or longer for efficient uptake of soil moisture [51].

At the physiological level, drought stress reduces stomatal conductance and increases transpiration rate [23]. This causes an unbalanced transpiration rate and results in low leaf relative water content (LRWC) [53]. Water potential, water use efficiency, and hydraulic conductivity in drought-stressed plants are remarkably reduced, whereas leaf venation density is increased, indicating that water deficit negatively interferes with the water transportation in leaves [37]. Photosynthesis, an important biological process for plant survival, is significantly influenced by drought. These include the reduction of leaf carbon dioxide assimilation, ribulose-1,5-bisphosphate (RuBP) regeneration [22], chlorophyll and carotenoid contents, and accessory pigments [53].

At the biochemical level, drought stress induces a high level of ROS, which can lead to cellular damage. To respond, plants close their stomata to limit gas exchange. The reduced carbon dioxide levels in chloroplasts decrease NADP+ regeneration, causing higher leakage of electrons to oxygen $\left(\mathrm{O}_{2}\right)$ to form superoxide anions $\left(\mathrm{O}_{2}{ }^{\bullet-}\right)$ and subsequently, leading to the accumulation of ROS. If drought becomes severe, the reduced rate of chloroplast ATP synthesis increases the mitochondrial respiration rate, which eventually induces the accumulation of more ROS in the mitochondria [54]. In plants, increased lipid peroxidation (MDA); lipoxygenase (LOX) activity; aldehyde, proline, cysteine, and electrolyte leakage; and hydrogen peroxide $\left(\mathrm{H}_{2} \mathrm{O}_{2}\right)$ production have been used to assess the increase of ROS production under drought [55]. Several Calvin-Benson cycle enzyme activities, such as RuBisCo, GAPDH, and phosphoribulokinase, have also been shown to be affected by drought stress [56].

At the molecular level, several genes and signal transduction pathways have been found to be important in drought stress responses. These include abscisic acid (ABA), strigolactone, lipid-derived signal, ROS, NO, transcription factors, and soluble sugars [57]. Plants perceive the external drought stimuli via sensors on the membrane and transmit them down the signals through multiple signal transduction pathways. This causes the changes in drought-responsive gene expression and adaptation. Drought-responsive genes are regulated by complex mechanisms, including the transcriptional cascades. Among the transcription factors, AP2/EREBP, WRKY, MYB, NAC, DREB, HSFF, and bZIP are commonly reported transcription factor families in drought stress response [58]. There are two groups of drought-responsive genes, i.e., ABA-dependent and ABA-independent. Many drought-responsive genes respond to ABA. These ABA-dependent genes encode the late embryogenesis abundant (LEA) proteins (the most reported ABA-dependent), enzymes (involved in the generation of osmolytes, detoxification, and metabolisms), transporters (ion transporters and channel proteins), transcription factors, and protein kinases. Some genes, however, do not respond to ABA. DREB2 proteins, members of the AP2/ERF transcription factor family, are among the important proteins in the ABA-independent pathway in response to drought stress conditions [59]. Most photosynthesis genes, such as Psas, Psbs, and Pets, have also been reported to be downregulated in drought-stressed plants, whereas antioxidant enzyme-related genes, including GSTs, PODs, CATs, SODs, and $G P X s$, as well as genes encoding the respiratory burst oxidase protein $(\mathrm{RBOH})$, have been found to be upregulated [46]. Other drought-responsive genes involved in transportation (aquaporin (PIP) gene), lipid and sugar metabolisms, wax synthesis, cell wall regulation, and osmotic adjustment have also been reported [60]. Besides changing the gene expression, 
drought stress also induces genotoxic alterations, such as DNA damage and mutational events [56].

To combat these adverse effects of drought stress, plants have some inbuilt mechanisms, such as enzymatic (superoxide dismutase (SOD), peroxidase (POD), catalase (CAT), glutathione peroxidase (GPX), and ascorbate peroxidase (APX)) and nonenzymatic antioxidant enzymes (phenolic compounds, flavonol, anthocyanin, tocopherol, ascorbic acid, carotenoids, and those involved in secondary metabolic biosynthesis like phenylalanine ammonia-lyase (PAL) and tyrosine ammonia-lyase (TAL)).

\subsection{The Involvement of NO in Drought Tolerance}

The role of NO in mitigating drought stress effects has been observed in several plant species, including grains, legumes, fruit trees, medicinal plants, and vegetables (Table 1). The production of NO depends on the drought stress level, exposure duration, and plant growth stages. For instance, the accumulation of $\mathrm{NO}$ in Cucumis sativus increased from 75-fold within the first $10 \mathrm{~h}$ of drought exposure to 190-fold after $17 \mathrm{~h}$ of drought exposure compared to well-watered plants [61]. Different types of nitrogen nutrition supplied to plants have been reported to influence the rapidness of endogenous NO production. Cao et al. [11] reported that rice supplemented with ammonium $\left(\mathrm{NH}_{4}{ }^{+}\right)$induced endogenous $\mathrm{NO}$ production after $3 \mathrm{~h}$ of drought treatment, whereas those supplemented with $\mathrm{NO}_{3}{ }^{-}$ induced $\mathrm{NO}$ production after $6 \mathrm{~h}$ of drought treatment. Their findings indicate that $\mathrm{NH}_{4}^{+}$ is more effective than $\mathrm{NO}_{3}{ }^{-}$in alleviating water stress, probably due to the early $\mathrm{NO}$ burst which might be triggered by NOS-like enzymes in roots.

Exogenous application of NO-induced stomatal closure in Tradescantia sp., Salpichroa organifolia, and Vicia faba [62]. The saturated net carbon dioxide assimilation rate, stomatal conductance, substomatal carbon dioxide concentration, and transpiration rate were also increased after NO treatment [37]. By applying the NO scavenger 2-phenyl-4,4,5,5,tetramethylimidazoline-1-oxyl 3-oxide (PTIO), stomatal closure was inhibited, supporting the notion that $\mathrm{NO}$ is induced endogenously and most likely could act as a signaling element to facilitate stomatal closure. In addition, NO may promote the formation of guard cells and influence the distribution of stomata in the abaxial leaf [63]. 
Table 1. Recent studies of nitric oxide on drought stress.

\begin{tabular}{|c|c|c|c|c|c|c|}
\hline Plant & $\begin{array}{l}\text { Drought } \\
\text { Imposition } \\
\text { and Duration }\end{array}$ & $\begin{array}{l}\text { Source of } \\
\text { NO }\end{array}$ & $\begin{array}{l}\text { Concentration } \\
(\mu \mathrm{mol} / \mathrm{L})\end{array}$ & $\begin{array}{l}\text { Application } \\
\text { Method }\end{array}$ & $\begin{array}{l}\text { Response under Water } \\
\text { Deficit Condition }\end{array}$ & Reference \\
\hline \multirow[t]{2}{*}{$\begin{array}{l}\text { Alfalfa } \\
\text { (Medicago } \\
\text { sativa L.) }\end{array}$} & $\begin{array}{l}10 \% \text { of } P E G \\
\text { for } 7 d\end{array}$ & SNP & 100 & $\begin{array}{l}\text { Seeds were } \\
\text { germinated on } \\
\text { filter papers } \\
\text { containing } \\
\text { treatment } \\
\text { solutions (SNP } \\
\text { and PEG) }\end{array}$ & $\begin{array}{l}\text { Increment of the fresh } \\
\text { weight, LRWC, chlorophyll } \\
\text { content, proline content, } \\
\text { soluble sugar contents and } \\
\text { antioxidant enzyme } \\
\text { activities (NR, SOD, POD, } \\
\text { CAT, and APX), and } \\
\text { reduction of root length, } \\
\text { MDA level, differentially } \\
\text { expressed genes involved in } \\
\text { antioxidative defense } \\
\text { system, photosynthesis, } \\
\text { hormonal signal } \\
\text { transduction, carbohydrate } \\
\text { metabolism, and secondary } \\
\text { metabolism }\end{array}$ & {$[46]$} \\
\hline & $\begin{array}{l}\text { Withholding } \\
\text { water for } 6 \mathrm{~d}\end{array}$ & $\begin{array}{l}\text { NOSH or } \\
\text { NOSH-A }\end{array}$ & 100 & Foliar spray & $\begin{array}{l}\text { Improved acclimation to } \\
\text { drought stress and improved } \\
\text { the recovery after } \\
\text { re-watering by reducing } \\
\text { lipid peroxidation and } \\
\text { proline accumulation levels }\end{array}$ & [21] \\
\hline $\begin{array}{l}\text { Apple } \\
\text { rootstocks } \\
\text { (Malus spp.) }\end{array}$ & $\begin{array}{l}\text { Withholding } \\
\text { water for } 7 \mathrm{~d}\end{array}$ & SNP & $\begin{array}{l}50,100,200 \\
300, \text { and } 400\end{array}$ & $\begin{array}{l}\text { Foliar spray } \\
(5 \text { times per } \mathrm{d})\end{array}$ & $\begin{array}{l}\text { Protection of Malus seedlings } \\
\text { from drought-induced } \\
\text { oxidative damage by } \\
\text { enhancing antioxidant } \\
\text { enzyme activities and } \\
\text { photosynthetic performance }\end{array}$ & [64] \\
\hline $\begin{array}{l}\text { Banana (Musa } \\
\text { acuminata } \mathrm{cv} \text {. } \\
\text { Berangan) }\end{array}$ & $\begin{array}{l}5 \% \text { PEG for } \\
9 \mathrm{~d}\end{array}$ & SNP & 5 & $\begin{array}{l}\text { SNP was } \\
\text { supplied in liquid } \\
\text { MS medium }\end{array}$ & $\begin{array}{l}\text { Increment of the dry weight, } \\
\text { number of roots formed, and } \\
\text { antioxidant enzyme } \\
\text { activities (SOD, CAT, APX, } \\
\text { and GR); reduction of the } \\
\text { percentage of yellow leaves }\end{array}$ & [65] \\
\hline $\begin{array}{l}\text { Broccoli } \\
\text { (Brassica } \\
\text { oleracea L.) }\end{array}$ & $\begin{array}{l}60 \% \text { field } \\
\text { capacity for } \\
21 \mathrm{~d}\end{array}$ & SNP & 20 & $\begin{array}{l}\text { Pre-sowing } \\
\text { (seeds were } \\
\text { soaked with SNP } \\
\text { for } 15 \mathrm{~h} \text { ) or foliar } \\
\text { spray once }\end{array}$ & $\begin{array}{l}\text { Enhancement of the fresh } \\
\text { and dry biomass of shoot, } \\
\text { shoot length, chlorophyll } \\
\text { contents, GB, total phenolics, } \\
\text { total soluble proteins, and } \\
\text { activities of SOD and POD } \\
\text { enzymes under water } \\
\text { deficiency }\end{array}$ & [31] \\
\hline $\begin{array}{l}\text { Canola } \\
\text { (Brassica } \\
\text { napus L. } \\
\text { Dunkeld and } \\
\text { L. Cyclone) }\end{array}$ & $\begin{array}{l}60 \% \text { field } \\
\text { capacity for } \\
21 \mathrm{~d}\end{array}$ & SNP & 20 & Foliar spray once & $\begin{array}{l}\text { Upregulation of the } \\
\text { oxidative defense system, } \\
\text { osmoprotectant } \\
\text { accumulation, and } \\
\text { minimizing the lipid } \\
\text { peroxidation. }\end{array}$ & [66] \\
\hline $\begin{array}{l}\text { Common } \\
\text { bean } \\
\text { (Phaseolus } \\
\text { vulgaris L. cv. } \\
\text { IAC Mile^- } \\
\text { nio) }\end{array}$ & $\begin{array}{l}\text { PEG (osmotic } \\
\text { potential of - } \\
0.3 \mathrm{MPa} \text { ) for } \\
12 \text { and } 17 \mathrm{~d}\end{array}$ & GSNO & $\begin{array}{l}50,100,500 \\
1000, \text { and } \\
2000\end{array}$ & $\begin{array}{l}\text { Pre-sowing } \\
\text { (seeds were } \\
\text { soaked with } \\
\text { GSNO for } 1 \mathrm{~min} \text { ) }\end{array}$ & $\begin{array}{l}\text { Improvement of seed } \\
\text { germination and increment } \\
\text { of initial root growth }\end{array}$ & [25] \\
\hline
\end{tabular}


Table 1. Cont

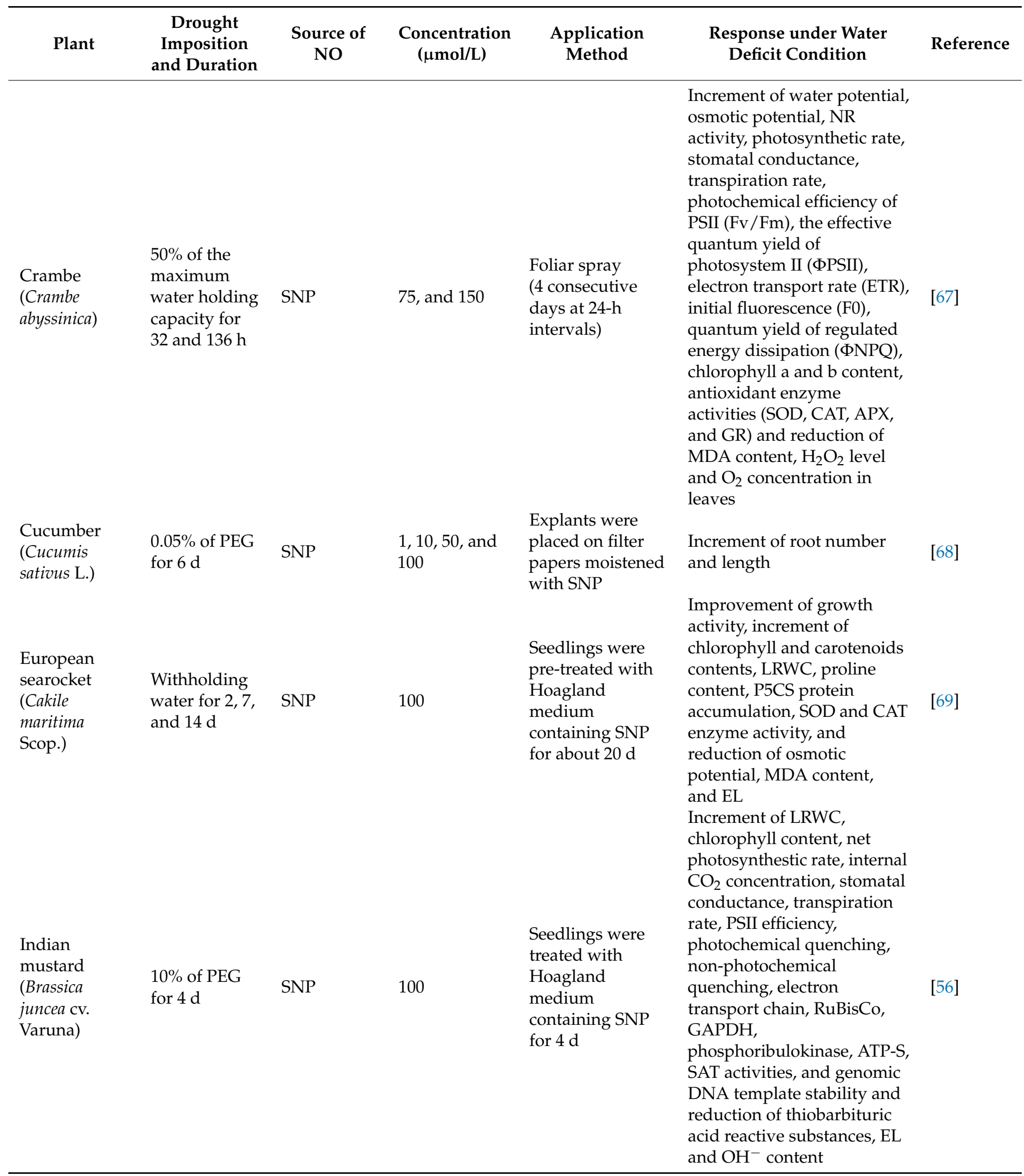


Table 1. Cont.

\begin{tabular}{|c|c|c|c|c|c|c|}
\hline Plant & $\begin{array}{c}\text { Drought } \\
\text { Imposition } \\
\text { and Duration }\end{array}$ & $\begin{array}{l}\text { Source of } \\
\text { NO }\end{array}$ & $\begin{array}{l}\text { Concentration } \\
(\mu \mathrm{mol} / \mathrm{L})\end{array}$ & $\begin{array}{l}\text { Application } \\
\text { Method }\end{array}$ & $\begin{array}{l}\text { Response under Water } \\
\text { Deficit Condition }\end{array}$ & Reference \\
\hline $\begin{array}{l}\text { Indian } \\
\text { mustard } \\
\text { (Brassica } \\
\text { juncea cv. } \\
\text { Pusa } \\
\text { Jagannath } \\
\text { and cv. } \\
\text { Varuna) }\end{array}$ & $\begin{array}{l}10 \% \text { of } P E G \\
\text { for } 4 \mathrm{~d}\end{array}$ & SNP & 100 & $\begin{array}{l}\text { Seedlings were } \\
\text { treated with } \\
\text { Hoagland } \\
\text { medium } \\
\text { containing SNP } \\
\text { for } 4 \mathrm{~d}\end{array}$ & $\begin{array}{l}\text { Brassica juncea cv. Pusa } \\
\text { Jagannath had the } \\
\text { antioxidant protection } \\
\text { mainly through the } \\
\text { accumulation of } \\
\text { nonenzymatic antioxidants, } \\
\text { whereas Brassica juncea cv. } \\
\text { Varuna showed tolerance by } \\
\text { the enhancement of both } \\
\text { enzymatic and } \\
\text { nonenzymatic antioxidant } \\
\text { activities }\end{array}$ & [53] \\
\hline $\begin{array}{l}\text { Marjoram } \\
\text { (Origanum } \\
\text { majorana L. } \\
\text { German type) }\end{array}$ & $\begin{array}{l}70 \% \text { depletion } \\
\text { of available } \\
\text { soil water for } \\
95 \mathrm{~d}\end{array}$ & SNP & 30 and 60 & $\begin{array}{l}\text { Foliar spraying } \\
\text { using a } \\
\text { hand-atomizer on } \\
\text { days } 35,50,65 \text {, } \\
\text { and } 80\end{array}$ & $\begin{array}{l}\text { Improved water use } \\
\text { efficiency, increased plant } \\
\text { biomass and essential oil } \\
\text { yield and percentage, } \\
\text { phytopharmaceuticals of } \\
\text { herbal extract (ascorbic acid, } \\
\text { total soluble phenol, } \\
\text { anthocyanin, and flavonoid), } \\
\text { antioxidant enzyme } \\
\text { activities (CAT and POD), } \\
\text { plant extract reducing power } \\
\text { and reduction of } \mathrm{H}_{2} \mathrm{O}_{2}, \\
\text { MDA, protein carbonyl } \\
\text { group and percentage of EL }\end{array}$ & [70] \\
\hline $\begin{array}{l}\text { Milk thistle } \\
\text { (Silybum } \\
\text { marianum) }\end{array}$ & $\begin{array}{l}\text { Withholding } \\
\text { water for } 14 \mathrm{~d}\end{array}$ & SNP & 100 and 200 & $\begin{array}{l}\text { Whole plants } \\
\text { were sprayed } \\
\text { with SNP } 4 \text { times } \\
\text { using a wheeled } \\
\text { plot sprayer }\end{array}$ & $\begin{array}{l}\text { Increment of photosynthetic } \\
\text { rate, chlorophyll a, b and } \\
\text { carotenoid content, and seed } \\
\text { yield }\end{array}$ & [71] \\
\hline $\begin{array}{l}\text { Perennial } \\
\text { ryegrass } \\
\text { (Lolium } \\
\text { perenne L.) }\end{array}$ & $\begin{array}{l}\text { Withholding } \\
\text { water for } 23 \mathrm{~d}\end{array}$ & GSNO & 100 & $\begin{array}{l}\text { Foliar spray } \\
\text { every } 2 \mathrm{~d}\end{array}$ & $\begin{array}{l}\text { Increment of total } \\
\text { chlorophyll and carotenoids } \\
\text { content, 1-SST activity } \\
\text { associated with increased } \\
\text { fructan content, GR activity, } \\
\text { and S-nitrosothiols content } \\
\text { and reduction of MDA } \\
\text { content, } \mathrm{H}_{2} \mathrm{O}_{2} \text { level, and } \\
\text {.OH levels }\end{array}$ & [72] \\
\hline $\begin{array}{l}\text { Persian } \\
\text { shallot } \\
\text { (Allium } \\
\text { hirtifolium) }\end{array}$ & $\begin{array}{l}2,4,8 \text { and } \\
16 \mathrm{mmol} / \mathrm{L} \text { of } \\
\text { PEG for } \\
16 \text { weeks }\end{array}$ & SNP & 10,40 , and 70 & $\begin{array}{l}\text { SNP was } \\
\text { supplied in MS } \\
\text { medium }\end{array}$ & $\begin{array}{l}\text { Increment of regeneration } \\
\text { rate, LRWC content, } \\
\text { photosynthetic pigments, } \\
\text { antioxidant enzyme activity } \\
(\mathrm{SOD} \text { and } \mathrm{APX}) \text {, proline and } \\
\text { allicin accumulation, and } \\
\text { reduction of } \mathrm{H}_{2} \mathrm{O}_{2} \text {, and } \\
\text { MDA content in leaves }\end{array}$ & [73] \\
\hline $\begin{array}{l}\text { Physalis } \\
\text { angulata }\end{array}$ & $\begin{array}{l}80 \% \text { and } 20 \% \\
\text { field capacity } \\
\text { for } 20 \mathrm{~d}\end{array}$ & SNP & $\begin{array}{l}25,50,75, \text { and } \\
100\end{array}$ & $\begin{array}{l}\text { Foliar spray with } \\
\text { SNP twice per } \\
\text { experiment }\end{array}$ & $\begin{array}{l}\text { Low concentrations of SNP } \\
\text { have shown to mitigate } \\
\text { negative effects of water } \\
\text { deficit, improving } \\
\text { photosynthetic rates, } \\
\text { maintenance of leaf water } \\
\text { potential, and growth }\end{array}$ & [26] \\
\hline
\end{tabular}


Table 1. Cont.

\begin{tabular}{|c|c|c|c|c|c|c|}
\hline Plant & $\begin{array}{c}\text { Drought } \\
\text { Imposition } \\
\text { and Duration }\end{array}$ & $\begin{array}{l}\text { Source of } \\
\text { NO }\end{array}$ & $\begin{array}{l}\text { Concentration } \\
(\mu \mathrm{mol} / \mathrm{L})\end{array}$ & $\begin{array}{l}\text { Application } \\
\text { Method }\end{array}$ & $\begin{array}{l}\text { Response under Water } \\
\text { Deficit Condition }\end{array}$ & Reference \\
\hline $\begin{array}{l}\text { Rapeseed } \\
\text { (Brassica } \\
\text { napus cv. } \\
\text { BINA } \\
\text { Sarisha 3) }\end{array}$ & $\begin{array}{l}10 \% \text { and } 20 \% \\
\text { of PEG for } 2 \mathrm{~d}\end{array}$ & SNP & 500 & $\begin{array}{l}\text { Seedlings were } \\
\text { pre-treated with } \\
\text { Hyponex solution } \\
\text { containing SNP }\end{array}$ & $\begin{array}{l}\text { Improvement of the levels of } \\
\text { nonenzymatic antioxidant } \\
\text { pool, glyoxalase system, and } \\
\text { upregulation of antioxidant } \\
\text { enzyme activities }\end{array}$ & [74] \\
\hline $\begin{array}{l}\text { Safflower } \\
\text { (Carthamus } \\
\text { tinctorius L.) }\end{array}$ & $\begin{array}{l}20 \% \text { of field } \\
\text { capacity for } \\
21 \mathrm{~d}\end{array}$ & SNP & 25 & $\begin{array}{l}\text { Whole plants } \\
\text { were sprayed } \\
\text { with SNP }(1 \mathrm{~d} \\
\text { before and } 7 \mathrm{~d} \\
\text { after drought } \\
\text { stress treatments) }\end{array}$ & $\begin{array}{l}\text { Improvement of the growth } \\
\text { of aerial part, increment of } \\
\text { chlorophyll content, and } \\
\text { reduction of anthocyanin, } \\
\text { flavonoid and phenol } \\
\text { contents, and root length }\end{array}$ & [51] \\
\hline $\begin{array}{l}\text { Rice } \\
\text { (Oryza sativa L. } \\
\text { 'Zhongzheyou } \\
\text { No. 1' hybrid } \\
\text { indica) }\end{array}$ & $\begin{array}{l}10 \% \text { of PEG } \\
\text { for } 21 \mathrm{~d}\end{array}$ & SNP & 20 & $\begin{array}{l}\text { Seedlings were } \\
\text { treated with SNP } \\
\text { solution once }\end{array}$ & $\begin{array}{l}\text { Increment of antioxidant } \\
\text { activities (CAT, APX, and } \\
\mathrm{SOD}) \text {, and reduction of } \\
\mathrm{O}_{2}^{\bullet-}, \mathrm{H}_{2} \mathrm{O}_{2}, \mathrm{OH}^{-} \text {, and } \\
\mathrm{ONOO}^{-} \text {content, MDA, and } \\
\text { carbonyl levels in root }\end{array}$ & [11] \\
\hline \multirow{3}{*}{$\begin{array}{l}\text { Soybean } \\
\text { (Glycine max) }\end{array}$} & $\begin{array}{l}20 \% \text { water in } \\
\text { the soil for } \\
30 \mathrm{~d}\end{array}$ & SNP & 100 & $\begin{array}{l}\text { Foliar spray in } 3 \\
\mathrm{~d} \text { intervals }\end{array}$ & $\begin{array}{l}\text { Increment of photosynthesis } \\
\text { and biomass accumulation }\end{array}$ & [37] \\
\hline & $\begin{array}{l}5,10, \text { and } 15 \% \\
\text { of PEG for } \\
21 \mathrm{~d}\end{array}$ & SNP & 100 & $\begin{array}{l}\text { Whole plants } \\
\text { were sprayed } \\
\text { with SNP using } \\
\text { an atomizer on } \\
\text { alternate day }\end{array}$ & $\begin{array}{l}\text { Increment of FW, SOD, CAT, } \\
\text { POX, APX, PPO enzyme } \\
\text { activities, phenylalanine } \\
\text { ammonia-lyase, and tyrosine } \\
\text { ammonia-lyase activities, } \\
\text { total phenol, flavonol, and } \\
\text { tocopherol content, and } \\
\text { reduction of } \mathrm{MDA} \text { content, } \\
\text { aldehyde, } \mathrm{H}_{2} \mathrm{O}_{2} \text { content, } \\
\text { LOX activity, and EL }\end{array}$ & [55] \\
\hline & $\begin{array}{l}15 \% \text { of } P E G \\
\text { for } 2 \mathrm{~d}\end{array}$ & SNP & $\begin{array}{l}50,100,200 \\
400, \text { and } 600\end{array}$ & $\begin{array}{l}\text { SNP was } \\
\text { supplied in } \\
\text { Hoagland } \\
\text { medium }\end{array}$ & $\begin{array}{l}\text { Positively regulated the } \\
\text { transcription of genes } \\
\text { encoding Cyt-G6PD (GPD5, } \\
\text { G6PD6, and G6PD7) }\end{array}$ & [75] \\
\hline $\begin{array}{l}\text { Stevia } \\
\text { rebaudiana } \\
\text { Bertoni }\end{array}$ & $\begin{array}{l}5 \%, 10 \% \text { and } \\
15 \% \text { of } P E G \\
\text { for } 20,40 \text { and } \\
60 \mathrm{~d}\end{array}$ & SNP & $\begin{array}{l}50,100,250, \\
\text { and } 500\end{array}$ & $\begin{array}{l}\text { SNP was } \\
\text { supplied in MS } \\
\text { medium }\end{array}$ & $\begin{array}{l}\text { Increment of shoot length, } \\
\text { shoot number, and leaf } \\
\text { number }\end{array}$ & [52] \\
\hline $\begin{array}{l}\text { Sugarcane } \\
\text { (Saccharum } \\
\text { spp.) }\end{array}$ & $\begin{array}{l}\text { PEG } \\
\text { treatment for } \\
7 \mathrm{~d} \\
(-0.75 \mathrm{MPa})\end{array}$ & $\begin{array}{l}\mathrm{NO}_{3}{ }^{-}: \mathrm{NH}_{4}{ }^{+} \\
\text {ratios 100:0 } \\
\text { and } 70: 30\end{array}$ & 5 & $\begin{array}{l}\mathrm{NO}_{3}^{-}: \mathrm{NH}_{4} \text { was } \\
\text { supplied in } \\
\text { nutrient solution; } \\
\text { plantlets were } \\
\text { cultured in the } \\
\text { medium for } 2 \\
\text { weeks before } \\
\text { drought stress } \\
\text { treatment }\end{array}$ & $\begin{array}{l}\text { Increment of photosynthetic } \\
\text { rate, stomatal conductance, } \\
\text { root growth, and reduction } \\
\text { of ROS accumulation in } \\
\text { plants treated with more } \\
\text { nitrate }\end{array}$ & [32] \\
\hline
\end{tabular}


Table 1. Cont.

\begin{tabular}{|c|c|c|c|c|c|c|}
\hline Plant & $\begin{array}{c}\text { Drought } \\
\text { Imposition } \\
\text { and Duration }\end{array}$ & $\begin{array}{c}\text { Source of } \\
\text { NO }\end{array}$ & $\begin{array}{l}\text { Concentration } \\
(\mu \mathrm{mol} / \mathrm{L})\end{array}$ & $\begin{array}{l}\text { Application } \\
\text { Method }\end{array}$ & $\begin{array}{l}\text { Response under Water } \\
\text { Deficit Condition }\end{array}$ & Reference \\
\hline & $\begin{array}{l}\text { PEG } \\
\text { treatment } \\
\text { for } 5 \mathrm{~d} \\
(-0.75 \mathrm{MPa})\end{array}$ & GSNO & $\begin{array}{l}10,100 \\
500, \text { and } 1000\end{array}$ & $\begin{array}{l}\text { Foliar spray twice } \\
\text { per day }\end{array}$ & $\begin{array}{l}\text { Increment of photochemical } \\
\text { activity, LRWC, leaf, and } \\
\text { root dry matter }\end{array}$ & [76] \\
\hline $\begin{array}{l}\text { Thyme } \\
\text { (Thymus } \\
\text { serpyllum } \\
\text { Serpolet and } \\
\text { T. Vulgaris L.). }\end{array}$ & $\begin{array}{l}80,60 \text { and } \\
40 \% \text { field } \\
\text { capacity }\end{array}$ & SNP & $\begin{array}{l}50,100,150, \\
\text { and } 200\end{array}$ & $\begin{array}{l}\text { Whole plants } \\
\text { were sprayed } \\
\text { with SNP } 3 \text { times } \\
\text { per experiment } \\
\text { (prior to } \\
\text { flowering stage, } \\
\text { at } 50 \% \text { flowering, } \\
\text { and at full bloom) }\end{array}$ & $\begin{array}{l}\text { Increment of proline } \\
\text { accumulation and reduction } \\
\text { of some antioxidant } \\
\text { activities which increased } \\
\text { drought tolerance }\end{array}$ & [77] \\
\hline $\begin{array}{l}\text { Tomato } \\
\text { (Lycopersicon } \\
\text { esculentum } \\
\text { Mill.) }\end{array}$ & $\begin{array}{l}\text { Withholding } \\
\text { water for } 7 \mathrm{~d}\end{array}$ & SNP & 50 and 100 & $\begin{array}{l}\text { Foliar spray on } \\
\text { alternate day } \\
\text { after } 1 \mathrm{~d} \text { of water } \\
\text { holding }\end{array}$ & $\begin{array}{l}\text { Improvement of drought } \\
\text { tolerance by increasing SOD } \\
\text { activity, reducing } \mathrm{H}_{2} \mathrm{O}_{2} \text {, and } \\
\text { other physiological } \\
\text { processes (increased leaf } \\
\text { number, average number of } \\
\text { flower clusters per plant, } \\
\text { LRWC, and lycopene } \\
\text { content) }\end{array}$ & [78] \\
\hline $\begin{array}{l}\text { Watermelon } \\
\text { (Citrullus } \\
\text { lanatus var. } \\
\text { lanatus KAR } \\
\text { 98) }\end{array}$ & $\begin{array}{l}15 \% \text { of } P E G \\
\text { for } 10 \mathrm{~d}\end{array}$ & SNP & 100 & $\begin{array}{l}\text { SNP was } \\
\text { supplied in } \\
\text { Hoagland } \\
\text { medium; the } \\
\text { medium was } \\
\text { replaced every } \\
3 \mathrm{~d}\end{array}$ & $\begin{array}{l}\text { Increment of root length, } \\
\text { APX, GR antioxidant } \\
\text { activities, and reduction of } \\
\text { MDA content, } \mathrm{OH}^{-}, \text {osmotic } \\
\text { potential, and EL }\end{array}$ & [79] \\
\hline $\begin{array}{l}\text { Wheat } \\
\text { (Triticum } \\
\text { aestivum L. cv. } \\
\text { Pishgam) }\end{array}$ & $\begin{array}{l}\text { Soil moisture } \\
\text { at } 75 \% \text { and } \\
50 \% \text { for } 6 \\
\text { weeks }\end{array}$ & SNP & 100 & Foliar spray & $\begin{array}{l}\text { Increment of seedling length, } \\
\text { SOD enzyme activity, total } \\
\text { soluble proteins, net } \\
\text { photosynthetic rate, and } \\
\text { intercellular carbon dioxide } \\
\text { concentration and reduction } \\
\text { of } \mathrm{H}_{2} \mathrm{O}_{2} \text {, and MDA contents }\end{array}$ & [23] \\
\hline $\begin{array}{l}\text { Wheat } \\
\text { (Triticum } \\
\text { aestivum L. cv. } \\
\text { Prodip) }\end{array}$ & $\begin{array}{l}15 \% \text { and } 30 \% \\
\text { of PEG for } 9 \mathrm{~d}\end{array}$ & SNP & 0.5 & $\begin{array}{l}\text { SNP was } \\
\text { supplied in } \\
\text { Hyponex solution }\end{array}$ & $\begin{array}{l}\text { Enhancement of the } \\
\text { antioxidant defense system } \\
\text { (both nonenzymatic and } \\
\text { enzymatic components) in } \\
\text { drought-stressed seedlings, } \\
\text { endogenous NO content, } \\
\text { glyoxalase system, and } \\
\text { reduction of methylglyoxal } \\
\text { content, which restored the } \\
\text { LRWC, and further } \\
\text { increased the proline content }\end{array}$ & [80] \\
\hline $\begin{array}{l}\text { Wheat } \\
\text { (Triticum } \\
\text { aestivum } \mathrm{cv} \text {. } \\
\text { Jing 852) }\end{array}$ & $\begin{array}{l}7.5 \% \text { of } P E G \\
\text { for } 5 \mathrm{~d}\end{array}$ & SNP & 5 & $\begin{array}{l}\text { SNP was } \\
\text { supplied in } \\
\text { Hoagland } \\
\text { medium }\end{array}$ & $\begin{array}{l}\text { Increment of lateral and } \\
\text { primary root length }\end{array}$ & [81] \\
\hline
\end{tabular}


Table 1. Cont.

\begin{tabular}{|c|c|c|c|c|c|c|}
\hline Plant & $\begin{array}{c}\text { Drought } \\
\text { Imposition } \\
\text { and Duration }\end{array}$ & $\begin{array}{c}\text { Source of } \\
\text { NO }\end{array}$ & $\begin{array}{l}\text { Concentration } \\
(\mu \mathrm{mol} / \mathrm{L})\end{array}$ & $\begin{array}{l}\text { Application } \\
\text { Method }\end{array}$ & $\begin{array}{l}\text { Response under Water } \\
\text { Deficit Condition }\end{array}$ & Reference \\
\hline $\begin{array}{l}\text { Wheat } \\
\text { (Triticum } \\
\text { aestivum cv. } \\
\text { BARS-2009 } \\
\text { and Triticum } \\
\text { aestivum cv. } \\
\text { Mairaj-2008) } \\
\text { Wheat }\end{array}$ & $\begin{array}{l}35 \% \text { of water } \\
\text { holding } \\
\text { capacity till } \\
\text { physiological } \\
\text { maturity }\end{array}$ & SNP & $\begin{array}{l}50,100, \text { and } \\
150\end{array}$ & $\begin{array}{l}\text { Foliar spray ( } 7 \mathrm{~d} \\
\text { before drought } \\
\text { stress treatment) } \\
\text { using a hand } \\
\text { sprayer }\end{array}$ & $\begin{array}{l}\text { Increment of yield, } \\
\text { chlorophyll contents, } \\
\text { accumulation of soluble } \\
\text { phenolics, proline, and GB, } \\
\text { and reduction of MDA } \\
\text { contents }\end{array}$ & [82] \\
\hline $\begin{array}{l}\text { (Triticum } \\
\text { aestivum } \mathrm{cv} . \\
98 \mathrm{SN} 146 \text { and } \\
\text { Triticum } \\
\text { aestivum cv. } \\
\text { Longchun22) }\end{array}$ & PEG for $24 \mathrm{~h}$ & SNP & 100 & $\begin{array}{l}\text { Seedlings were } \\
\text { pre-sprayed with } \\
\text { SNP (12 h before } \\
\text { drought stress } \\
\text { treatment) }\end{array}$ & $\begin{array}{l}\text { Increment of } \\
\text { cyanide-resistant respiration, } \\
\text { pyruvate content, Alternative } \\
\text { oxidase gene }(A O X 1 a) \text {, and } \\
\text { alternative pathway }\end{array}$ & [83] \\
\hline $\begin{array}{l}\text { White clover } \\
\text { (Trifolium } \\
\text { repens) }\end{array}$ & $\begin{array}{l}\text { PEG }(-0.3 \\
\text { Mpa) for } 8 \mathrm{~d}\end{array}$ & SNP & 50 & $\begin{array}{l}\text { SNP was } \\
\text { supplied in } \\
\text { Hoagland } \\
\text { medium; } \\
\text { plantlets were } \\
\text { cultured in the } \\
\text { medium for } 3 \mathrm{~d} \\
\text { before drought } \\
\text { stress treatment }\end{array}$ & $\begin{array}{l}\text { Effectively mitigated water } \\
\text { stress damage; changes of } \\
\text { metabolic profiles, and } \\
\text { associated metabolic } \\
\text { pathways which could } \\
\text { contribute to enhance stress } \\
\text { tolerance }\end{array}$ & [84] \\
\hline
\end{tabular}

APX, ascorbate peroxidase; CAT, catalase; EL, electrolyte leakage; ETR, electron transport rate; F0, initial fluorescence; GAPDH, glyceraldehyde-3-phosphate dehydrogenase; GB, glycine betaine; GSNO, S-nitrosoglutathione; $\mathrm{H}_{2} \mathrm{O}_{2}$, hydrogen peroxide; LRWC, leaf relative water content; MDA, malondialdehyde; MS, Murashige and Skoog medium; NOSH-A, NOSH-aspirin; $\mathrm{NR}$, nitrate reductase; ${ }_{2}^{\bullet-}$, superoxide anion radical; $\mathrm{O}_{2}$, oxygen; $\mathrm{OH}^{-}$, hydroxyl radical; $\mathrm{ONOO}-$, peroxynitrite; $\mathrm{PEG}$, polyethylene glycol; $\mathrm{PPO}$, polyphenol oxidase; POD, peroxidase; PRK, phosphoribulokinase; RuBisCo, ribulose 1,5-bisphosphate carboxylase/oxygenase; SNP, sodium nitroprusside; SOD, superoxide dismutase; $\Phi$ PSII, photosystem II; $\Phi$ NPQ, quantum yield of regulated energy dissipation.

At the molecular level, NO induces the expression of stress-related genes in response to drought stress. For instance, NO positively regulated the transcription of stress-adaptationrelated genes, i.e., Cyt-G6PD (GPD5, G6PD6, and G6PD7) in soybean roots [75]. Zhao et al. [46] found that more than 2000 genes were differentially expressed in droughtstressed alfalfa plants treated with or without NO. These differentially expressed genes are involved in several critical cellular and physiological processes, such as the antioxidative defense system, photosynthesis, hormonal signal transduction, carbohydrate metabolism, and secondary metabolism [46]. When Shi et al. [85] exposed the rat neuronal NO synthase (nNOS)-expressing transgenic Arabidopsis to drought, they found that the gene expression profile (184 genes upregulated and 263 downregulated) and antioxidant enzymatic activities were changed. Endogenous NO has also been found to improve the stability of genomic DNA in drought-stressed plants, such as Indian mustard [56], Brassica rapa [86], and Oryza sativa [87]. These findings highlight the importance of NO in drought stress tolerance. However, the details regarding NO signaling and its crosstalk with other molecules are still unclear and require further exploration.

\subsection{The Involvement of NO in the Antioxidant System}

NO regulates the levels of cellular ROS and toxicity through two main pathways, enzymatic and nonenzymatic antioxidant enzymes (Figure 3) [88]. Majeed et al. [35] reported that the level of MDA and $\mathrm{H}_{2} \mathrm{O}_{2}$ in drought-stressed maize was reduced by almost 50\% after $\mathrm{NO}$ treatment [35]. The reduction of $\mathrm{H}_{2} \mathrm{O}_{2}$ and $\mathrm{O}_{2}{ }^{-}$might be due to the enhanced antioxidative defense activities of NO [84]. Activities of SOD, CAT, and APX have been observed to be influenced by NO. With NO treatment, Rezayian et al. [55] found that activities of SOD, CAT, APX, PPO, and POX in soybean under a mild drought condition 
(5\% polyethylene glycol (PEG)) were higher than under moderate (10\% PEG) and severe $(15 \%)$ drought conditions. The application of an NO donor, i.e., SNP, increased CAT activity in PEG-induced drought-stressed rice, whereas PEG alone decreased CAT activity [11]. At the mRNA level, it has been shown that endogenously induced or exogenously introduced NO triggered upregulation of antioxidative defense genes, including OsCATA, OsCATB, and OsPOX1 in rice [89]; $C u / Z n-S O D$ in maize [90]; GSTs, PODs, CATs, SODs, and GPXs in alfalfa, but downregulation of $\mathrm{RBOH}$ gene [46].

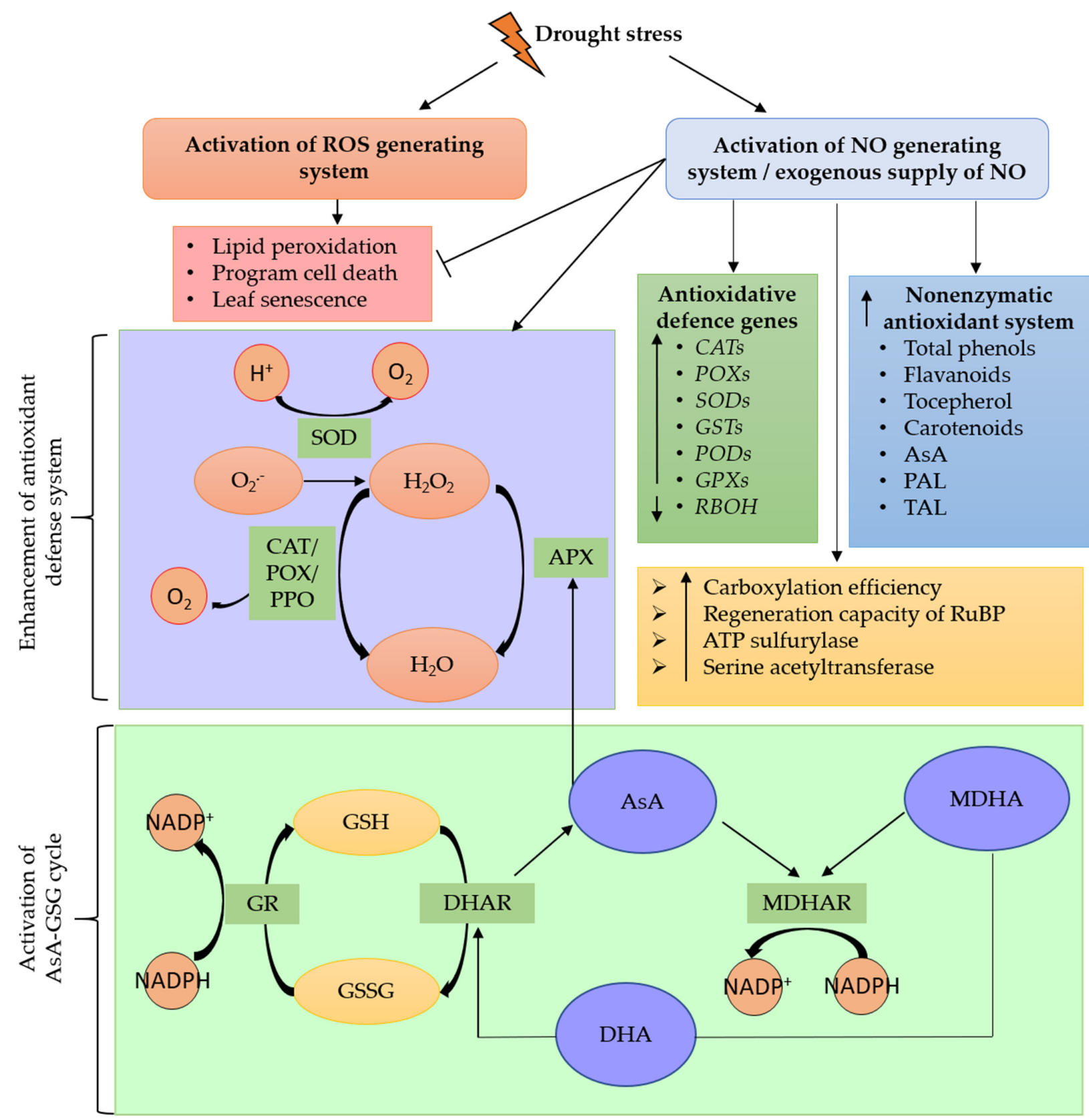

Figure 3. Activation of enzymatic and nonenzymatic antioxidant systems by nitric oxide (NO) to detoxify cellular reactive oxygen species (ROS) induced by drought stress. APX, ascorbate peroxidase; AsA, ascorbate; ATP, Adenosine triphosphate; CAT, catalase; DHA, dehydroascorbate; DHAR, dehydroascorbate reductase; GPX, glutathione peroxidase; GR, glutathione reductase; GSH, reduced glutathione; GSSG, oxidized glutathione; GST, glutathione S-transferase; $\mathrm{H}^{+}$, hydrogen ion; $\mathrm{H}_{2} \mathrm{O}_{2}$, hydrogen peroxide; MDHA, monodehydroascorbate; MDHAR, monodehydroascorbate reductase; $\mathrm{NADP}^{+}$, nicotinamide adenine dinucleotide phosphate; $\mathrm{NADPH}$, reduced form of nicotinamide adenine dinucleotide phosphate; $\mathrm{O}_{2}^{\bullet-}$, superoxide anion; PAL, phenylalanine ammonia-lyase; POD and POX, peroxidases; PPO, polyphenol oxidase; RBOH, respiratory burst oxidase protein; RuBP, ribulose-1,5-bisphosphate; SOD, superoxide dismutase; TAL, tyrosine ammonia-lyase. 
It is well known that drought stress could activate leaf senescence and programmed cell death. NO has been reported to act as a negative regulator of leaf senescence and programmed cell death. During leaf senescence, a gradual decline in antioxidants and an increase in ROS are detected. NO could delay leaf senescence by enhancing CAT and SOD activities and inducing the production of other enzymes, such as s-transferase, alternative oxidase, and glutathione (GSH) [91]. To mitigate oxidative damage caused by ROS, NO increases the carboxylation efficiency, regeneration capacity of RuBP, as well as ATP-sulfurylase and serine acetyltransferase activities [56]. As a signal mediator, NO is also involved in cold- and starvation-stress-induced programmed cell death in barley [92]. Jiang et al. [93] showed that the level of NO began to accumulate and achieved the highest value at the loading stage of cryopreservation in Dendrobium.

Nonenzymatic antioxidants also play a vital role in scavenging ROS. Among the nonenzymatic antioxidants, AsA, and GSH have the strongest protective effect against droughtinduced oxidative stress $[45,94]$. It has been reported that NO increased the accumulation of phenolic compounds, including total phenol, flavonol, and tocopherol, in soybean when exposed to water deficit conditions [55]. Both important phenolic biosynthetic enzymes, PAL and TAL, were also highly expressed by NO treatment [55]. Similar findings were reported in drought-stressed broccoli [31] and wheat [82]. Taken together, NO could act as a signaling molecule to maintain ROS homeostasis and enhance drought stress tolerance in plants by regulating antioxidant machinery.

\subsection{Synergistic Relationship of NO with Other Signaling Molecules}

$\mathrm{NO}$ mediates its action in a concerted way with other signaling molecules, including hydrogen sulfide $\left(\mathrm{H}_{2} \mathrm{~S}\right), \mathrm{H}_{2} \mathrm{O}_{2}$, calcium $\left(\mathrm{Ca}^{2+}\right)$, melatonin, and polyamines (PAs). $\mathrm{H}_{2} \mathrm{~S}$ is an important signaling molecule with effects on many biological processes, such as growth and development, as well as defense responses in plants [95]. Emerging evidence indicated that $\mathrm{H}_{2} \mathrm{~S}$ interacts with other signaling molecules to modify their signal. It is believed that the mechanisms of action of $\mathrm{H}_{2} \mathrm{~S}$ are via a PTM of proteins, called persulfidation [96]. In this modification, reactive cysteine residues on target proteins are modified by converting the thiol group (-SH) into a persulfide group (-SSH). These persulfidated proteins are believed to be involved in cellular functions and metabolic pathways, as well as protection against overoxidation.

The function of $\mathrm{H}_{2} \mathrm{~S}$ in stomatal closure under drought stress has been shown to be mediated by NO. By exogenously applying $\mathrm{H}_{2} \mathrm{~S}$ to Vicia faba, Garcia-Mata and Lamattina [62] found that $\mathrm{H}_{2} \mathrm{~S}$ induced stomatal closure through the regulation of ATP-binding cassette $(\mathrm{ABC})$ transporters. This effect can be reverted by cPTIO (2-(4-carboxyphenyl)4,4,5,5 tetramethylimidazoline-1-oxyl-3-oxide) (an NO-specific scavenger), suggesting the synergistic effect of $\mathrm{NO}$ and $\mathrm{H}_{2} \mathrm{~S}$. Antoniou et al. [21] found that alfalfa plants adapted to drought stress conditions after being pretreated with $\mathrm{NO}$ and $\mathrm{H}_{2} \mathrm{~S}$. They indicated that $\mathrm{NO}$ and $\mathrm{H}_{2} \mathrm{~S}$ treatment improved vitality, turgor, greening of leaves, stomatal conductance, and chlorophyll content [21]. Besides improving the morphophysiology of plants, NO, together with $\mathrm{H}_{2} \mathrm{~S}$, has also been found to improve antioxidant enzyme activities, such as those of APX, GR, POX, SOD, and CAT, and enhance the accumulation of osmolytes (proline and glycine betaine). These effects were reversed by the NO scavenger, cPTIO, indicating the protective role of both molecules against drought stress [97].

$\mathrm{H}_{2} \mathrm{O}_{2}$ is a signaling molecule that regulates plant metabolism by cooperating with other signaling molecules. Its production can be stimulated by NO [98]. Together, they modulate the accumulation of osmolytes, regulate ABA-induced antioxidant enzyme activities, induce stomatal closure, protect mesophyll cell ultrastructure, and improve photosynthesis [99-102]. When priming the wheat seedlings with $\mathrm{NO}$ and $\mathrm{H}_{2} \mathrm{O}_{2}$, Wang et al. [99] found that the tolerance level of pretreated wheat seedlings was enhanced. The accumulation of proline and glycine betaine was also increased [99].

$\mathrm{Ca}^{2+}$ is a secondary messenger regulating many physiological processes in plants. $\mathrm{NO}$ has been shown to govern $\mathrm{Ca}^{2+}$ homeostasis, in addition to almost all types of 
$\mathrm{Ca}^{2+}$ channels and transporters. In plants, $\mathrm{NO}$ increases the cytosolic $\mathrm{Ca}^{2+}$ concentration when under stress conditions. The increased cytosolic $\mathrm{Ca}^{2+}$ concentration, on the other hand, induces NO biosynthesis through calcium-binding proteins, suggesting that $\mathrm{NO}$ and $\mathrm{Ca}^{2+}$ can synergistically improve plant tolerance to adverse environmental conditions like drought. Several studies have been carried out to elucidate the relationship between these two signaling molecules. NO was first found as a $\mathrm{Ca}^{2+}$-mobilizing messenger in plants when studies evaluated the ability of NO donors in increasing the intracellular $\mathrm{Ca}^{2+}$ concentration $[103,104]$. Lamotte et al. [103] showed that diethylamine NONOate (NO donor) induced a transient rise in cytosolic $\mathrm{Ca}^{2+}$ concentration in transgenic Nicotiana plumbaginifolia, whereas application of the NO scavenger cPTIO and NOS inhibitors decreased the cytosolic $\mathrm{Ca}^{2+}$ concentration. However, Rodríguez-Serrano et al. [105] reported that the production of $\mathrm{NO}$ was increased by addition of $\mathrm{Ca}^{2+}$. Two mechanisms of action of $\mathrm{NO}$ on $\mathrm{Ca}^{2+}$ channel and transporter activities have been reported: a cGMPdependent mechanism and a cGMP-independent mechanism. The mechanism of the cGMP-dependent pathway is complex. At least three processes have been reported to date: (i) cGMP directly activates cyclic nucleotide-gated channels to produce cytosolic free $\mathrm{Ca}^{2+}$; (ii) cGMP could be mediated through the activation of protein kinases (PKG); (iii) activation of PKG is a crucial step in NO-induced cyclic ADP-ribose (cADPR) synthesis. The cGMP/PKG/cADPR cascade has now been recognized as a mechanism where NO induces $\mathrm{Ca}^{2+}$ signals in various physiological processes. For the cGMP-independent mechanism, the effects of $\mathrm{NO}$ on $\mathrm{Ca}^{2+}$ homeostasis are through the S-nitrosylation of $\mathrm{Ca}^{2+}$ channels and transporters. Increasing evidence indicates that $\mathrm{Ca}^{2+}$ mediates plant adaptation to drought stress conditions. For example, $\mathrm{Ca}^{2+}$ has been shown to mediate stomatal movements in Arabidopsis under drought conditions [106]. Foresi et al. [107] reported that stomatal closure can be triggered by $\mathrm{NO}$ through regulation of $\mathrm{Ca}^{2+}$-sensitive potassium ion $\left(\mathrm{K}^{+}\right)$ and chloride ion $\left(\mathrm{Cl}^{-}\right)$channels at the plasma membrane of guard cells. Other studies showed that $\mathrm{Ca}^{2+}$ and $\mathrm{NO}$ synergize to counteract drought stress effects by inducing initial root growth and development $[25,68]$.

Similar to animal systems, the interactions between NO and melatonin in plants have been suggested to be both positive and antagonistic toward each other. Melatonin plays an important role in plant growth and modulation of defense responses [108]. Its protective roles in biotic and abiotic stresses have been widely investigated. Liang et al. [109] found that long-term exogenous application of melatonin improved nutrient uptake in apple plants under moderate drought conditions. The level of endogenous NO can be influenced by exogenous application of melatonin and vice versa. For example, exogenous application of melatonin increased NO production in alfalfa [110] and Arabidopsis [111]. It is believed that the interaction of NO and melatonin is through a cGMP-dependent pathway [112]. Although melatonin has been shown to positively regulate NOS-mediated NO biosynthesis in neuronal cells [113], as well as inducing mitochondrial NOS mRNA expression and protein synthesis [114], this molecule may suppress NOS activity during nitrosative stress [110]. Antagonistic interactions between melatonin and NO have been reported in root growth regulation in Arabidopsis during aluminum stress [115]. The authors found that exogenous melatonin could inhibit root growth in Arabidopsis during aluminum stress and decrease $\mathrm{NO}$ accumulation in roots.

PAs are polycationic molecules that are present in all living organisms. In plants, the most abundant PAs are putrescine (PUT), spermidine (SPD), and spermine (SPM). PAs are involved in various cellular processes, such as cell division and elongation, morphogenesis, and flowering [116]. PAs can also act as protective compounds to enhance plant tolerance against abiotic stresses [117]. Several studies demonstrated that PAs are involved in the production of $\mathrm{H}_{2} \mathrm{O}_{2}$ and $\mathrm{NO}[118,119]$. This was evidenced by exogenously applying PAs on the drought-stressed plants like Arabidopsis [120], white clover [16], and cucumber seedlings [121]. The NO production was found to be increased in those plants, whereas this effect was reversed by the SPD synthase inhibitor (DCHA) [16]. In contrast, Montilla-Bascón et al. [122] reported that NO production was reduced in transgenic barley 
plants overexpressing the class 1 barley hemoglobin gene, $H v H b 1$, an effective scavenger of endogenous NO. They found that the reduced NO level increased PA biosynthesis and ethylene biosynthetic genes, suggesting that NO might crosstalk with ethylene to regulate the expression of key enzymes in the PA biosynthetic pathways, such as arginine decarboxylase, ornithine decarboxylase, and methionine adenosyltransferase.

Taken together, these findings suggest a crosstalk between NO and other signaling molecules in drought stress adaptation. A better understanding of the interplay among these signaling molecules will undoubtedly enhance our current knowledge of the mechanisms triggered in plants against different stresses.

\subsection{Crosstalk Between NO and Plant Hormones}

Phytohormones play an important role in various processes, such as plant growth and development, as well as adaptation to biotic and abiotic stresses. Emerging evidence supports the notion that NO interplays with phytohormones, such as ABA, auxins, cytokinins (CKs), and ethylene, to regulate these biological processes [123]. For instance, NO has been found to crosstalk with ABA, jasmonic acid (JA), salicylic acid (SA), and CKs to mitigate the adverse effect of drought stress.

$\mathrm{ABA}$, an isoprenoid class of plant hormones, is well known as an antistress phytohormone which can rapidly accumulate under environmental stresses [124]. It is well-known that ABA can stimulate stomatal closure. Stomatal closure is one of the earliest plant responses to drought conditions. The purpose of the closure of stomata is to reduce the transpiration rate and ion leakage, which in turn decreases the rate of photosynthesis [76]. When plants are exposed to drought stress, a significant amount of ABA is produced. Once the $\mathrm{ABA}$ molecules reach guard cells via the $\mathrm{ABC}$ transporter, they bind to the pyrabactin resistance1/PYR1-like/regulatory components of ABA (PYR/PYL/RCAR) receptors to trigger a complex signaling network that leads to the stomatal closure (Figure 4). This signaling network involves the participation of several signaling molecules, such as $\mathrm{Ca}^{2+}, \mathrm{NO}$, and $\mathrm{H}_{2} \mathrm{O}_{2}$; protein kinases; and transcription factors. Previous reports demonstrated that NO generation is essential for ABA-induced stomatal closure and that ABA can increase NO generation in the guard cells. There are numerous NO targets that have been identified in ABA-regulated signal transduction. These include plasma membrane calcium-dependent anion and $\mathrm{K}+$ channels, protein phosphatase $2 \mathrm{C}$ (PPC2), and sucrose non fermenting 1 (SNF1)-related protein kinase 2.6 (SnRK2.6). It was shown that NO activated plasma membrane calcium-dependent anion channels but deactivated the inward-rectifying $\mathrm{K}+$ channels in the guard cells [125], resulting in the loss of turgor pressure that causes stomatal closure [126]. Desikan et al. [127] reported that PP2C mutants (ABA-insensitive abi1-1 and abi2-1) generated $\mathrm{NO}$ in response to $\mathrm{ABA}$ but failed to close the stomata in response to $\mathrm{NO}$, suggesting that $\mathrm{PP} 2 \mathrm{C}$ might be downstream of $\mathrm{NO}$ in the ABA signaling cascade. The interaction between NO and ABI1 might be mediated by the GC/cGMP pathway [128]. Wang et al. [129] reported that NO negatively regulates ABA signaling in guard cells by inhibiting SnRK2.6 through S-nitrosylation. Several ABA-responsive genes have also been reported to be affected by NO treatment. These include AtHVA22H [130], WRKY TF ABO3 [131], and AtWRKY 62 genes [132]. Taken together, both NO and ABA are important plant signaling molecules that work together to regulate redox balance and homeostasis against drought stress. 


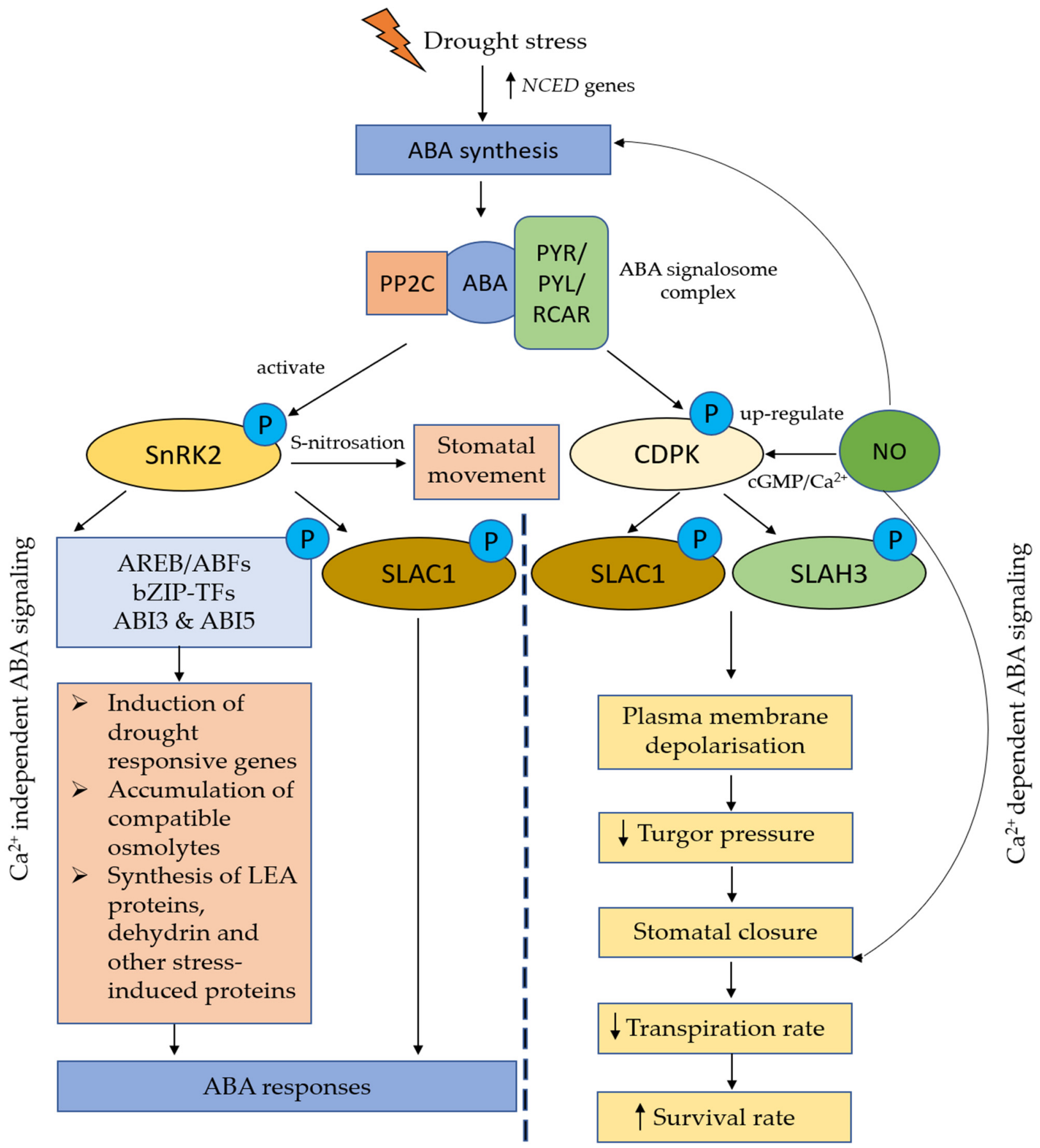

Figure 4. Schematic diagram showing crosstalk between abscisic acid (ABA) and nitric oxide (NO) under drought stress. Drought stress activates the regulation of 9-cis-epoxycarotenoid dioxygenase (NCED) gene to enhance biosynthesis of ABA at leaf vascular parenchyma cells, which are the primary sites for ABA biosynthesis. ABA molecule binds to the pyrabactin resistance1/PYR1-like/regulatory components of ABA (PYR/PYL/RCAR) receptors and protein phosphatase 2C (PPC2) to form ABA signalosome complexes. These ABA signalosome complexes phosphorylate either (I) sucrose nonfermenting 1 (SNF1)-related protein kinase 2 (SnRK2) in $\mathrm{Ca}^{2+}$ independent ABA signaling pathway or (II) calciumdependent protein kinase (CDPK) in $\mathrm{Ca}^{2+}$ dependent ABA signaling. In $\mathrm{Ca}^{2+}$ independent ABA signaling pathway, SnRK2 proteins phosphorylated AREB/ABF, b-ZIP, ABI3, and ABI5 transcription factors to induce expression of drought-responsive genes, accumulation of compatible osmolytes, as well as synthesis of LEA proteins, dehydrin, and other stress-induced proteins or ion channels (e.g., SLAC1), and subsequently trigger ABA responses. In $\mathrm{Ca}^{2+}$ dependent ABA signaling pathway, CDPKs are activated by NO. The increase of $\mathrm{Ca}^{2+}$ and phosphorylated ion channels [SLAC1 and S-type anion channel 3 (SLAH3)] trigger a cascade of ABA responses. These include plasma membrane depolarization, decrease of turgor pressure, stomatal closure, and reduction of transpiration rate. 
JA is a lipid-based hormone signal. It is an important endogenous regulator that controls various processes, including seed germination, senescence, and stress adaptation [133]. It is known that JA triggers a cascade of reactions, but only a few of them have connections with NO signaling. Evidence shows that JA could enhance NO synthesis in the guard cell, and the synergistic effect of JA and NO is able to induce stomatal movement and stomatal closure [134]. The JA- and NO-induced stomatal closure can be reversed by the NO scavenger. Exogenous application of NO induces the expression of JA biosynthesis-related genes, including 12-oxophytodienoate reductases (OPR1, OPR2, and OPR3) and lipoxygenases (LOX3 and a putative lipoxygenase protein) [135]. Jian and $\mathrm{Wu}$ [136] reported that exogenously supplied methyl jasmonate could induce a rapid production of NO in Taxus cell cultures. They also found that other stress indicators, such as $\mathrm{H}_{2} \mathrm{O}_{2}$, MDA content, lipoxygenase, and PAL activities, were also increased after methyl jasmonate treatment. NO and JA show a synergistic relationship during drought conditions. For example, exogenous JA was found to enhance the drought tolerance in wheat by inducing NO production and upregulating the activity of the ascorbate-glutathione (AsA-GSH) cycle [137]. These findings show the interplay of NO and JA signaling in stress responses and adaptation; however, examination of the mechanism of these molecules in response to drought stress is scarce and requires further investigation.

Like ABA and JA, SA plays an important role in plant biological processes. Its relationship with $\mathrm{NO}$, both synergistic or antagonistic, has been reported. SA was found to induce the production of NO in Arabidopsis [138] but reduce the NO production in tomato root tips $[139,140]$. This antagonistic effect of NO and SA might be influenced by the concentration of SA [138]. Recent studies indicated that NO and SA were able to enhance plant growth in terms of shoot length; biomass accumulation; leaf number and area; chlorophyll, carotenoid, and flavonoid content [51], in addition to inducing stomatal closure [141].

CKs play significant roles in plant growth and developmental processes, including cell division, leaf senescence, and chloroplast biogenesis [142]. A possible involvement of NO in cytokinin signal transduction was first reported in Amaranthus caudatus seedlings, where the production of the red pigment betalaine was influenced by not only CKs but also NO [143]. Since then, many reports have shown that NO production could be triggered by CKs $[144,145]$. Similar to NO, both CKs and auxins have been shown to regulate stomatal behavior. However, it is yet to be determined if cytokinin- and auxin-induced stomatal opening is related to NO in guard cells. It was reported that $\mathrm{NO}$ acts downstream of CKs [145]. The interactions of NO and CKs are, however, complex and may be synergistic and antagonistic. In maize, the combination of $\mathrm{NO}$ and CKs was able to enhance photosynthetic performance in response to drought stress [144]. In contrast, Xiao-Ping and Xi-Gui [146] reported that CKs reduced NO levels in the SNP-treated guard cells in light and dark conditions, thereby promoting reopening of closed stomata. Their effects might be varied in regard to plant species and experimental approach. For instance, NO positively regulates the expression of CK biosynthetic genes (IPT1 and ZR) in the leaf tissues of Gossypium hirsutum [147], but NO-induced CKs reduce the NO level in Vicia faba [146]. Further research on this subject could help to further our understanding of how CKs and NO interact to respond to environmental stimuli.

At present, only a few studies have been carried out to investigate the relationship between phytohormones and NO in drought response. Our knowledge of their induction, production, and mechanism pathway of synergistic and antagonistic regulation remains limited, and continued efforts are needed to further elucidate how the pathways are interconnected. An overview of NO roles in alleviating drought stress at morphoanatomical, physiological, and biochemical levels in plants is illustrated in Figure 5. 


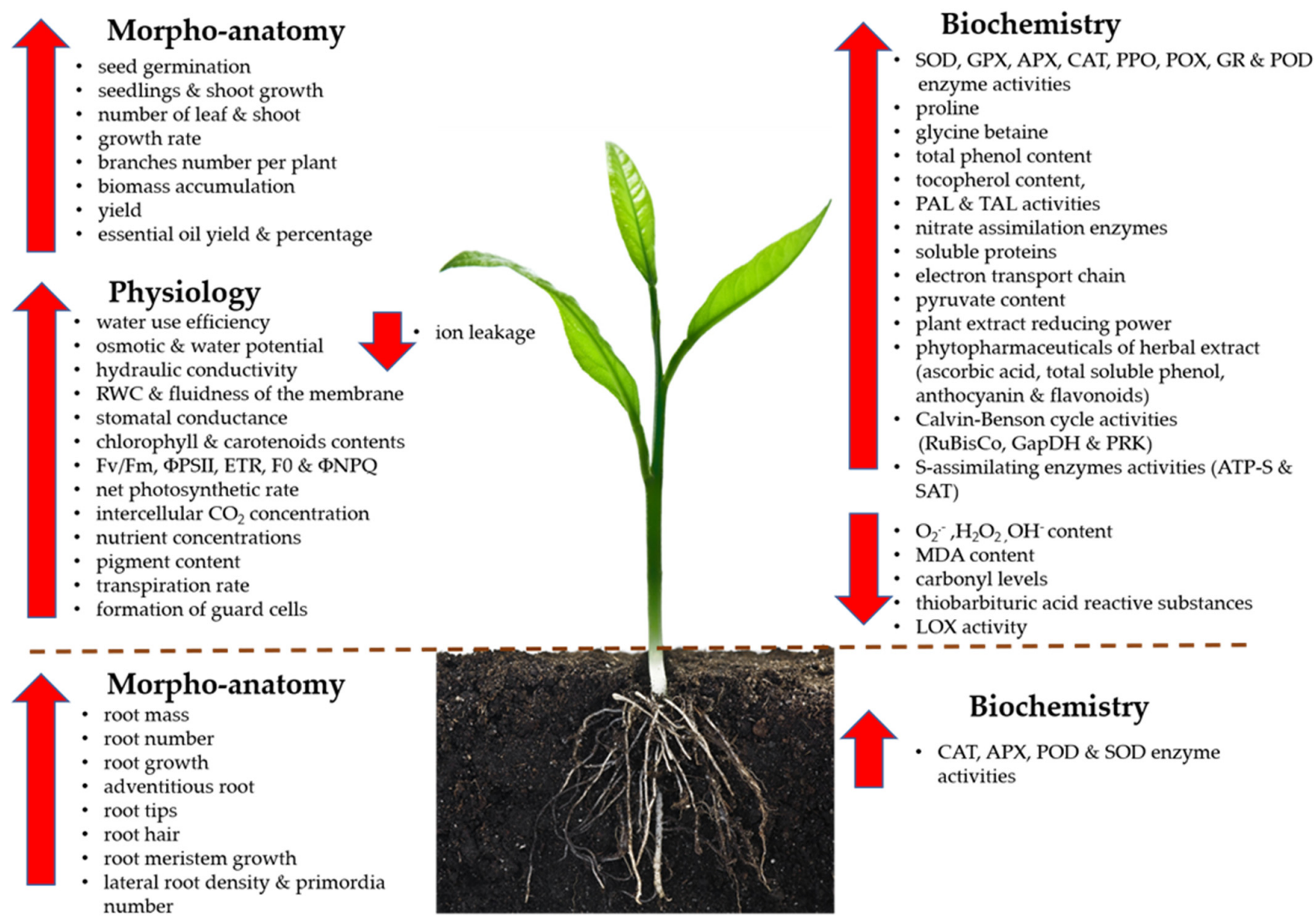

Figure 5. Overview of nitric oxide (NO) roles in alleviating drought stress at morpho-anatomical, physiological and biochemical levels in leaves and roots of a plant. $\Phi P S I I$, photosystem II; $\Phi$ NPQ, quantum yield of regulated energy dissipation; APX, ascorbate peroxidase; ATP-S, ATP-sulfurylase; CAT, catalase; ETR, electron transport rate; Fv/Fm, photochemical efficiency of photosystem II; GAPDH, glyceraldehyde-3-phosphate dehydrogenase; GPX, glutathione peroxidase; $\mathrm{GR}$, glutathione reductase; $\mathrm{H}_{2} \mathrm{O}_{2}$, hydrogen peroxide; LOX, lipoxygenase; POD and POX, peroxidases; PPO, polyphenol oxidase; $\mathrm{O}_{2}{ }^{--}$, superoxide anion; $\mathrm{O}_{2}$, oxygen; $\mathrm{OH}^{-}$, hydroxyl radical; PAL, phenylalanine ammonia-lyase; PRK, phosphoribulokinase; RuBisCo, ribulose 1,5-bisphosphate carboxylase/oxygenase; SAT, serine acetyltransferase; SOD, superoxide dismutase; TAL, tyrosine ammonia-lyase.

\section{NO-Responsive Proteins and Post-Translational Modifications}

NO acts mainly by the PTMs of proteins, via S-nitrosylation, metal nitrosylation, carbonylation, and tyrosine nitration [148]. Generally, PTMs regulate the functions and stability of key molecules involved in important cellular processes, such as proteolytic degradation or subcellular localization. Defining NO-mediated PTM (NO-PTM) proteins and their mechanisms in the context of drought is thus essential for understanding how NO regulates biological functions.

$S$-nitrosylation is the most common NO-PTM that covalently links an NO group to a cysteine thiol of a protein to form SNOs [149]. Numerous S-nitrosylated proteins have been reported in plants. These $S$-nitrosylated proteins are able to regulate the activity of their target proteins, such as protein cleavage [150], signaling and ROS generation or scavenging [151], and disease resistance [152]. NO through S-nitrosylation of SnRK2 proteins was found to suppress the inhibitory effect of ABA on germination and cotyledon development [153]. In addition, the increased S-nitrosothiol content was associated with an improvement in initial seedling growth in common bean [25] and Arabidopsis [153]. Nitrosylation/denitrosylation of ascorbate peroxidase 1 (APX1) and histidine phosphotransfer protein 1 (AHP1) could regulate root development and architecture [154] and 
CK signaling [155], respectively. GSNO, formed by S-nitrosylation of the antioxidant glutathione, is a major regulator of NO-SNO signaling by acting as an $\mathrm{NO}$ reservoir in cells [156]. Emerging evidence indicates that SNOs may be the key players in NO-signaling pathways involved in plant immunity and response to abiotic stresses by modulating the antioxidant capacity in order to regulate the redox homeostasis [157-159]. Efforts should thus be made to identify the SNO-mediated processes and S-nitrosylated proteins under physiological or stress conditions.

Tyrosine nitration is the reaction of a nitrating agent with a tyrosine residue of any target protein that leads to the addition of a nitro group $\left(\mathrm{NO}_{2}\right)$ to one of the two equivalent ortho carbons of the aromatic ring of tyrosine residues, resulting in 3-nitrotyrosine [156]. This process is mediated by peroxynitrite and nitrogen dioxide [160]. This modification was first thought to be irreversible, but emerging evidence suggests that denitrification may occur, either enzymatically or nonenzymatically [161]. Tyrosine nitration is an important redox-mediated PTM in plants, but only a few studies have been reported [162,163]. Efforts to use physiological approaches to investigate the biological role of this PTM in plant physiology are indispensable to better understand the impact of NO.

Metal nitrosylation involves the addition of a NO group to a transition metal, forming a metal-nitrosyl complex. In animals, guanylate cyclase and cytochrome $c$ oxidase are examples of a protein whose function is regulated by metal nitrosylation [164]. In plants, reaction of hemoglobins with $\mathrm{NO}$ through metal nitrosylation has been reported to be part of a protection against NO burst [165].

Proteomic approaches have been widely used to identify proteins undergoing nitrosylation. We can now concomitantly identify the nitrosylated cysteines at the exact site of modification. The recent advances in proteomic technologies and mass spectrometry have substantially increased the number of identified proteins. More effort, however, must be put on enriching low abundance nitrosylated proteins, which can be due to either a low level of nitrosylation or simply to low abundance of the protein. Importantly, to better understand the functions of this PTM in plants, many identified S-nitrosylated proteins should be validated using candidate-specific approaches rather than proteomics analysis. Since the analysis of $S$-nitrosoproteome under drought conditions remains largely untapped, plant scientists should now investigate the underlying mechanisms and functional roles of protein nitrosylation and identify candidate proteins associated with water deficit. The molecular mechanisms controlling the nitrosylation level and the mechanisms of signal integration at the interface between the nitrosylation network and other PTMs and signaling molecules are among the topics that require further exploration [166].

\section{Detection of NO: Challenges}

The quantification of NO is technically challenging due to its unique chemical properties. NO is produced in subcellular compartments in a broad range of concentrations, from pico- to micro-molar. It diffuses freely across membranes and has a short half-life (seconds) in biological systems [167]. In addition, NO signaling displays a complicated temporal and spatial arrangements which further impedes its detection [167]. Due to its ubiquity and involvement in various intrasignaling processes, the analytical methods used for its detection and analysis should suit the biological model and take into account the distinct features of NO production and functions. For example, NO generation in barley infected by Blumeria graminis f. sp. hordei (powdery mildew) was reported by a subtle change in the induction of the epidermal or the formation of cell wall papillae, which can be very difficult to detect using only a gas-based NO detection system [168]. Due to these difficulties, questions have been raised regarding the roles of NO in certain biological processes and the specificity of the detection methods used.

Fluorescent probes have been widely used to detect cellular NO due to their excellent sensitivity and selectivity. Most fluorescent probes, however, not only bind to NO but also bind to its oxidation by-products, other reactive secondary species or divalent metals, such as dinitrogen trioxide $\left(\mathrm{N}_{2} \mathrm{O}_{3}\right), \mathrm{NO}_{3}{ }^{-}$, peroxidases, $\mathrm{H}_{2} \mathrm{O}_{2}$, ascorbic acid, dehydroascorbic 
acid, and calcium chloride [169]. One such example is diaminofluorescein (DAF) dyes (DAF2 and DAF-2DA). DAF dyes have been commonly used to detect NO in plants because these dyes are relatively cheap and can be visualized using fluorescence microscopy [170]. The basic principle of the assay involves the hydrolysis of the diacetate groups on the DAF2DA by cytosolic esterases to form the nonfluorescent compound, DAF-2. In the presence of NO, the DAF-2 compound is then converted to a fluorescent triazole derivative, DAF-2T, allowing researchers to localize NO production in the cells [171]. The main drawback of the DAF dye method is its tendency to react with other ROS, such as peroxidases and $\mathrm{H}_{2} \mathrm{O}_{2}$ [169]. Recently, an electrochemically based method using a homemade platinumor iridium-based electrochemical microsensor has been reported to provide real-time detection of NO production in plant cell suspension cultures [167]. In addition, another electrochemical sensing microbundle that can simultaneously measure $\mathrm{NO}, \mathrm{H}_{2} \mathrm{O}_{2}$, and $\mathrm{pH}$ under drought stress at various developmental stages was invented [172].

Chemiluminescence is a chemical assay used to detect NO based on NO reaction with ozone. Upon reacting with ozone, NO forms nitrogen dioxide at an excited state. As it decays into the ground state, it emits a photon that can be detected by a photomultiplier tube [173]. Since the photon emitted is proportional to the reacting NO, this allows a reliable estimation of NO. This method holds advantages over other NO detection methods due to its sensitivity (detection in the pmole range) and ability to directly measure NO in both aqueous and gaseous states [174]. The disadvantages of the chemiluminescence method include reading errors that could be introduced due to the sensitivity of the photomultiplier or changes in the light generated by the secondary source of light. Another disadvantage is that chemiluminescence only measures gaseous $\mathrm{NO}$ and no other forms of nitrogen or reactive nitrogen intermediates [170]. Thus, the considerable levels of NO that are oxidized in living tissues cannot be easily detected using this method.

"Spin-trapping" is a commonly used method involving the detection of a transient, reactive free radical using a high concentration of diamagnetic spin trap. This approach is known as electron paramagnetic resonance (EPR) spectroscopy (also known as electron spin resonance, ESR, or electron magnetic resonance, EMR) [175]. Since NO and superoxide are diatomic free radicals, their presence could be detected using this method. NO can be effectively measured in the gas phase using EPR; however, its signal is less sensitive in the liquid phase [176]. Since the steady-state level of NO is below the detectable limit of EPR, NO needs to be trapped in a more stable form to allow its proper detection. This is achieved by adding a reactive free radical to the double bond of a diamagnetic compound known as "spin trap," forming a more persistent and stable secondary free radical (radical adduct) [177]. An example is nitrone 5,5-dimethyl-1-pyrroline $\mathrm{N}$-oxide (DMPO) which is used to trap free radicals, such as superoxide and hydroxyl, to provide the radical adducts with a distinctive spectrum. Unlike superoxides, which are highly stable and allow direct measurement, NO depends on reaction with other free radicals or its ability to coordinate with iron ions for a more reliable measurement [178]. Although the use of EPR for NO detection is not as direct or sensitive as other detection methods (such as chemiluminescence or electrochemical methods), its application is more effective under certain conditions. For example, EPR is not sensitive to magnetic susceptibility effects (unlike nuclear magnetic resonance (NRM) spectroscopy) and does not need optical transparency, enabling the measurement of cells or tissues in turbid solutions or solid form.

Developing efficient and sensitive methods of detection is clearly indispensable for the accurate detection and quantification of NO. Mur et al. [168] suggested the use of more than one technique to detect NO. In a study by Bright et al. [179], a combination of the DAF dye technique and EPR spectroscopy was applied to measure NO production when hydrating pollen. Besson-Bard et al. [180] combined the NO probe DAF-2 and an electrochemical method to detect the role of cryptogein, a fungal elicitor, in increasing NO production under biotic stress in tobacco. A similar approach was used to measure NO production in tobacco suspension cells [170]. The recent advances in quantum cascade laser-based spectroscopy have offered new opportunities to measure gaseous NO based on 
the absorption of laser light by the NO molecules and provide online planta measurements of the dynamics of NO production. Despite its sensitivity, this detection technique also has its flaws, including unintended interferences with another species, unreliable sensitivity, and indirect measurement taken from the secondary NO species [122].

\section{Conclusions and Perspectives}

$\mathrm{NO}$ is an important signaling molecule in drought response and adaptation. Although a substantial amount of data exists to support the role of $\mathrm{NO}$ in response to drought, many questions remain unanswered regarding NO regulation and its biological roles. How is NO synthesized? Where is NO accumulated? How does exogenous NO interact with endogenous NO? Moreover, it is important to investigate how NO regulates crosstalk between other signaling molecules $\left(\mathrm{H}_{2} \mathrm{~S}\right.$, ROS, and ABA), phytohormones (JA, SA, and ethylene), organic compounds (PAs), calcium, and pleiotropic molecule (melatonin) in alleviating drought stress effects. Given that NO signaling is a complex network, the use of bioinformatics tools to process and analyze the omics dataset is crucial. In terms of experiments, the design and methodology should be scientifically sound and conducted in a careful manner to obtain reliable results. The use of whole mature plants instead of seedlings, protoplasts, and detached leaves or whole plants in growth chambers should be encouraged to decipher the role of $\mathrm{NO}$ in response to drought under field conditions in order to achieve practical prospects.

Unfortunately, there are no entirely satisfactory detection methods for NO. Each current method has its limitations. Developing efficient and sensitive methods for NO detection is thus indispensable for quantifying and tracing NO in vivo in different tissues and at different times. With the advancement of technology, it is expected that a significant amount of data from plant NO research may be revisited in the near future, helping to better interpret $\mathrm{NO}$ function.

Author Contributions: Conceptualization, S.-E.L., M.F.H., and B.C.T.; writing-original draft preparation, S.-E.L., M.F.H., T.-L.P., N.B.S., and B.C.T.; supervision, N.B.S. and B.C.T.; funding acquisition, B.C.T. All authors have read and agreed to the published version of the manuscript.

Funding: This research was funded by the Fundamental Research Grant Scheme (FRGS/1/2018/ STG03/UM/02/2; FP065-2018A) from the Ministry of Education Malaysia, Royal Society-Newton Advanced Fellowship (NA170200; IF004-2018) from the Academy of Sciences Malaysia, and RU Fund (RU005-2019; ST009-2019) from the University of Malaya.

Institutional Review Board Statement: Not applicable.

Informed Consent Statement: Not applicable.

Data Availability Statement: Not applicable.

Conflicts of Interest: The authors declare no conflict of interest.

\section{References}

1. Waqas, M.A.; Kaya, C.; Riaz, A.; Farooq, M.; Nawaz, I.; Wilkes, A.; Li, Y. Potential mechanisms of abiotic stress tolerance in crop plants induced by thiourea. Front. Plant Sci. 2019, 10, 1336. [CrossRef]

2. NOAA National Centers for Environmental Information: Billion-Dollar Weather and Climate Disasters: Overview. Available online: https: / / www.ncdc.noaa.gov/billions/ (accessed on 27 December 2020).

3. FAO 2018. 2017: The Impact of Disasters and Crises on Agriculture and Food Security. Available online: http://www.fao.org/3/ I8656EN/i8656en.pdf (accessed on 27 December 2020).

4. Zhou, H.; Chen, Y.; Zhai, F.; Zhang, J.; Zhang, F.; Yuan, X.; Xie, Y. Hydrogen sulfide promotes rice drought tolerance via reestablishing redox homeostasis and activation of ABA biosynthesis and signaling. Plant Physiol. Biochem. 2020, 155, 213-220. [CrossRef]

5. Cao, Y.; Luo, Q.; Tian, Y.; Meng, F. Physiological and proteomic analyses of the drought stress response in Amygdalus mira (Koehne) Yü et Lu roots. BMC Plant Biol. 2017, 17, 53. [CrossRef] [PubMed]

6. Kaya, C.; Ashraf, M.; Alyemeni, M.N.; Ahmad, P. Responses of nitric oxide and hydrogen sulfide in regulating oxidative defence system in wheat plants grown under cadmium stress. Physiol. Plant. 2020, 168, 345-360. [CrossRef] [PubMed] 
7. Del Castello, F.; Nejamkin, A.; Cassia, R.; Correa-Aragunde, N.; Fernández, B.; Foresi, N.; Lombardo, C.; Ramirez, L.; Lamattina, L. The era of nitric oxide in plant biology: Twenty years tying up loose ends. Nitric Oxide Biol. Chem. 2019, 85, 17-27. [CrossRef] [PubMed]

8. Tropea, T.; Wareing, M.; Greenwood, S.L.; Feelisch, M.; Sibley, C.P.; Cottrell, E.C. Nitrite mediated vasorelaxation in human chorionic plate vessels is enhanced by hypoxia and dependent on the NO-sGC-cGMP pathway. Nitric Oxide Biol. Chem. 2018, 80, 82-88. [CrossRef] [PubMed]

9. Astier, J.; Gross, I.; Durner, J. Nitric oxide production in plants: An update. J. Exp. Bot. 2018, 69, 3401-3411. [CrossRef]

10. León, J.; Costa-Broseta, Á. Present knowledge and controversies, deficiencies, and misconceptions on nitric oxide synthesis, sensing, and signaling in plants. Plant Cell Environ. 2020, 43, 1-15. [CrossRef] [PubMed]

11. Cao, X.; Zhu, C.; Zhong, C.; Zhang, J.; Wu, L.; Jin, Q.; Ma, Q. Nitric oxide synthase-mediated early nitric oxide burst alleviates water stress-induced oxidative damage in ammonium-supplied rice roots. BMC Plant Biol. 2019, 19, 108. [CrossRef]

12. Wang, B.L.; Tang, X.Y.; Cheng, L.Y.; Zhang, A.Z.; Zhang, W.H.; Zhang, F.S.; Liu, J.Q.; Cao, Y.; Allan, D.L.; Vance, C.P.; et al. Nitric oxide is involved in phosphorus deficiency-induced cluster-root development and citrate exudation in white lupin. New Phytol. 2010, 187, 1112-1123. [CrossRef]

13. Gupta, K.J.; Igamberdiev, A.U.; Manjunatha, G.; Segu, S.; Moran, J.F.; Neelawarne, B.; Bauwe, H.; Kaiser, W.M. The emerging roles of nitric oxide (NO) in plant mitochondria. Plant Sci. 2011, 181, 520-526. [CrossRef] [PubMed]

14. Bethke, P.C.; Badger, M.R.; Jones, R.L. Apoplastic synthesis of nitric oxide by plant tissues. Plant Cell 2004, 16, 332-341. [CrossRef] [PubMed]

15. Corpas, F.J.; Barroso, J.B. Peroxisomal plant nitric oxide synthase (NOS) protein is imported by peroxisomal targeting signal type 2 (PTS2) in a process that depends on the cytosolic receptor PEX7 and calmodulin. FEBS Lett. 2014, 588, 2049-2054. [CrossRef] [PubMed]

16. Peng, D.; Wang, X.; Li, Z.; Zhang, Y.; Peng, Y.; Li, Y.; He, X.; Zhang, X.; Ma, X.; Huang, L.; et al. NO is involved in spermidineinduced drought tolerance in white clover via activation of antioxidant enzymes and genes. Protoplasma 2016, 253, 1243-1254. [CrossRef] [PubMed]

17. Rümer, S.; Gupta, K.J.; Kaiser, W.M. Plant cells oxidize hydroxylamines to NO. J. Exp. Bot. 2009, 60, 2065-2072. [CrossRef] [PubMed]

18. Tan, B.C.; Chin, C.F.; Alderson, P. Effects of sodium nitroprusside on shoot multiplication and regeneration of Vanilla planifolia Andrews. Vitr. Cell. Dev. Biol. Plant 2013, 49, 626-630. [CrossRef]

19. Floryszak-Wieczorek, J.; Milczarek, G.; Arasimowicz, M.; Ciszewski, A. Do nitric oxide donors mimic endogenous NO-related response in plants? Planta 2006, 224, 1363-1372. [CrossRef]

20. Salahuddin, M.; Nawaz, F.; Shahbaz, M.; Naeem, M.; Zulfiqar, B.; Shabbir, R.N.; Hussain, R.A. Effect of exogenous nitric oxide (NO) supply on germination and seedling growth of mungbean (cv. Nm-54) under salinity stress. Legum. Res. 2017, 40, 846-852. [CrossRef]

21. Antoniou, C.; Xenofontos, R.; Chatzimichail, G.; Christou, A.; Kashfi, K.; Fotopoulos, V. Exploring the potential of nitric oxide and hydrogen sulfide (NOSH)-releasing synthetic compounds as novel priming agents against drought stress in Medicago sativa plants. Biomolecules 2020, 10, 120. [CrossRef]

22. Silveira, N.M.; Seabra, A.B.; Marcos, F.C.C.; Pelegrino, M.T.; Machado, E.C.; Ribeiro, R.V. Encapsulation of S-nitrosoglutathione into chitosan nanoparticles improves drought tolerance of sugarcane plants. Nitric Oxide Biol. Chem. 2019, 84, 38-44. [CrossRef]

23. Faraji, J.; Sepehri, A. Exogenous Nitric oxide improves the protective effects of $\mathrm{TiO}_{2}$ nanoparticles on growth, antioxidant system, and photosynthetic performance of wheat seedlings under drought stress. J. Soil Sci. Plant Nutr. 2020, 20, 703-714. [CrossRef]

24. Habib, N.; Ali, Q.; Ali, S.; Javed, M.T.; Zulqurnain Haider, M.; Perveen, R.; Shahid, M.R.; Rizwan, M.; Abdel-Daim, M.M.; Elkelish, A.; et al. Use of nitric oxide and hydrogen peroxide for better yield of wheat (Triticum aestivum L.) under water deficit conditions: Growth, osmoregulation, and antioxidative defense mechanism. Plants 2020, 9, 285. [CrossRef]

25. Silveira, N.M.; Ribeiro, R.V.; Prataviera, P.J.C.; Pissolato, M.D.; Pieretti, J.C.; Seabra, A.B.; Machado, E.C. Germination and initial growth of common bean plants under water deficit as affected by seed treatment with S-nitrosoglutathione and calcium chloride. Theor. Exp. Plant Physiol. 2020, 32, 49-62. [CrossRef]

26. da Silva Leite, R.; do Nascimento, M.N.; Tanan, T.T.; Gonçalves Neto, L.P.; da Silva Ramos, C.A.; da Silva, A.L. Alleviation of water deficit in Physalis angulata plants by nitric oxide exogenous donor. Agric. Water Manag. 2019, 216, 98-104. [CrossRef]

27. Tian, X.; Lei, Y. Nitric oxide treatment alleviates drought stress in wheat seedlings. Biol. Plant. 2006, 50, 775-778. [CrossRef]

28. Yamasaki, H. Nitrite-dependent nitric oxide production pathway: Implications for involvement of active nitrogen spicies in photoinhibition in vivo. Philos. Trans. R. Soc. B Biol. Sci. 2000, 355, 1477-1488. [CrossRef] [PubMed]

29. Clyde Hill, A.; Bennett, J.H. Inhibition of apparent photosynthesis by nitrogen oxides. Atmos. Environ. 1970, 4, 341-348. [CrossRef]

30. Zottini, M.; Formentin, E.; Scattolin, M.; Carimi, F.; Lo Schiavo, F.; Terzi, M. Nitric oxide affects plant mitochondrial functionality in vivo. FEBS Lett. 2002, 515, 75-78. [CrossRef]

31. Munawar, A.; Akram, N.A.; Ahmad, A.; Ashraf, M. Nitric oxide regulates oxidative defense system, key metabolites and growth of broccoli (Brassica oleracea L.) plants under water limited conditions. Sci. Hortic. 2019, 254, 7-13. [CrossRef]

32. Pissolato, M.D.; Silveira, N.M.; Prataviera, P.J.C.; Machado, E.C.; Seabra, A.B.; Pelegrino, M.T.; Sodek, L.; Ribeiro, R.V. Enhanced nitric oxide synthesis through nitrate supply improves drought tolerance of sugarcane plants. Front. Plant Sci. 2020, 11, 970. [CrossRef] 
33. Senthil Kumar, R.; Shen, C.H.; Wu, P.Y.; Suresh Kumar, S.; Hua, M.S.; Yeh, K.W. Nitric oxide participates in plant flowering repression by ascorbate. Sci. Rep. 2016, 6, 35246. [CrossRef]

34. Zuccarelli, R.; Rodríguez-Ruiz, M.; Lopes-Oliveira, P.J.; Pascoal, G.B.; Andrade, S.C.S.; Furlan, C.M.; Purgatto, E.; Palma, J.M.; Corpas, F.J.; Rossi, M.; et al. Multifaceted roles of nitric oxide in tomato fruit ripening: NO-induced metabolic rewiring and consequences for fruit quality traits. J. Exp. Bot. 2020, in press. [CrossRef]

35. Majeed, S.; Nawaz, F.; Naeem, M.; Ashraf, M.Y.; Ejaz, S.; Ahmad, K.S.; Tauseef, S.; Farid, G.; Khalid, I.; Mehmood, K. Nitric oxide regulates water status and associated enzymatic pathways to inhibit nutrients imbalance in maize (Zea mays L.) under drought stress. Plant Physiol. Biochem. 2020, 155, 147-160. [CrossRef] [PubMed]

36. Yang, J.; Zhao, S.; Zhao, B.; Li, C. Overexpression of TaLEA3 induces rapid stomatal closure under drought stress in Phellodendron amurense Rupr. Plant Sci. 2018, 277, 100-109. [CrossRef] [PubMed]

37. de Sousa, L.F.; de Menezes-Silva, P.E.; Lourenço, L.L.; Galmés, J.; Guimarães, A.C.; da Silva, A.F.; dos Reis Lima, A.P.; Henning, L.M.M.; Costa, A.C.; Silva, F.G.; et al. Improving water use efficiency by changing hydraulic and stomatal characteristics in soybean exposed to drought: The involvement of nitric oxide. Physiol. Plant. 2020, 168, 576-589. [CrossRef]

38. Ji, Y.; Liu, J.; Xing, D. Low concentrations of salicylic acid delay methyl jasmonate-induced leaf senescence by up-regulating nitric oxide synthase activity. J. Exp. Bot. 2016, 67, 5233-5245. [CrossRef] [PubMed]

39. Ozfidan-Konakci, C.; Yildiztugay, E.; Elbasan, F.; Kucukoduk, M.; Turkan, I. Hydrogen sulfide (H2S) and nitric oxide (NO) alleviate cobalt toxicity in wheat (Triticum aestivum L.) by modulating photosynthesis, chloroplastic redox and antioxidant capacity. J. Hazard. Mater. 2020, 388. [CrossRef] [PubMed]

40. París, R.; Vazquez, M.M.; Graziano, M.; Terrile, M.C.; Miller, N.D.; Spalding, E.P.; Otegui, M.S.; Casalongué, C.A. Distribution of endogenous NO regulates early gravitropic response and PIN2 localization in Arabidopsis roots. Front. Plant Sci. 2018,9 , 495. [CrossRef] [PubMed]

41. Wang, Y.; Chen, T.; Zhang, C.; Hao, H.; Liu, P.; Zheng, M.; BaluÅka, F.; Åamaj, J.; Lin, J. Nitric oxide modulates the influx of extracellular $\mathrm{Ca}^{2+}$ and actin filament organization during cell wall construction in Pinus bungeana pollen tubes. New Phytol. 2009, 182, 851-862. [CrossRef] [PubMed]

42. Nasir, N.N.M.; Ho, C.L.; Lamasudin, D.U.; Saidi, N.B. Nitric oxide improves tolerance to Fusarium oxysporum f. sp. cubense Tropical Race 4 in banana. Physiol. Mol. Plant Pathol. 2020, 111, 4-9. [CrossRef]

43. Verma, N.; Tiwari, S.; Singh, V.P.; Prasad, S.M. Nitric oxide in plants: An ancient molecule with new tasks. Plant Growth Regul. 2020, 90. [CrossRef]

44. Nabi, R.B.S.; Tayade, R.; Hussain, A.; Kulkarni, K.P.; Imran, Q.M.; Mun, B.G.; Yun, B.W. Nitric oxide regulates plant responses to drought, salinity, and heavy metal stress. Environ. Exp. Bot. 2019, 161, 120-133. [CrossRef]

45. Hasanuzzaman, M.; Bhuyan, M.H.M.B.; Zulfiqar, F.; Raza, A.; Mohsin, S.M.; Al Mahmud, J.; Fujita, M.; Fotopoulos, V. Reactive oxygen species and antioxidant defense in plants under abiotic stress: Revisiting the crucial role of a universal defense regulator. Antioxidants 2020, 9, 681. [CrossRef] [PubMed]

46. Zhao, Y.; Wei, X.; Long, Y.; Ji, X. Transcriptional analysis reveals sodium nitroprusside affects alfalfa in response to PEG-induced osmotic stress at germination stage. Protoplasma 2020, 257, 1345-1358. [CrossRef] [PubMed]

47. Sun, C.; Lu, L.; Liu, L.; Liu, W.; Yu, Y.; Liu, X.; Hu, Y.; Jin, C.; Lin, X. Nitrate reductase-mediated early nitric oxide burst alleviates oxidative damage induced by aluminum through enhancement of antioxidant defenses in roots of wheat (Triticum aestivum). New Phytol. 2014, 201, 1240-1250. [CrossRef] [PubMed]

48. Khan, M.N.; Mobin, M.; Mohammad, F.; Corpas, F.J. Nitric oxide and high temperature stress: A physiological perspective. In Nitric Oxide Action in Abiotic Stress Responses in Plants, 1st ed.; Khan, M.N., Mobin, M., Mohammad, F., Corpas, F.J., Eds.; Springer International Publishing: Cham, Switzerland, 2015; pp. 77-93.

49. Ahmad, P.; Rasool, S.; Gul, A.; Sheikh, S.A.; Akram, N.A.; Ashraf, M.; Kazi, A.M.; Gucel, S. Jasmonates: Multifunctional roles in stress tolerance. Front. Plant Sci. 2016, 7. [CrossRef] [PubMed]

50. Sohag, A.A.M.; Tahjib-Ul-Arif, M.; Afrin, S.; Khan, M.K.; Hannan, M.A.; Skalicky, M.; Mortuza, M.G.; Brestic, M.; Hossain, M.A.; Murata, Y. Insights into nitric oxide-mediated water balance, antioxidant defence and mineral homeostasis in rice (Oryza sativa L.) under chilling stress. Nitric Oxide Biol. Chem. 2020, 100-101, 7-16. [CrossRef] [PubMed]

51. Chavoushi, M.; Najafi, F.; Salimi, A.; Angaji, S.A. Effect of salicylic acid and sodium nitroprusside on growth parameters, photosynthetic pigments and secondary metabolites of safflower under drought stress. Sci. Hortic. 2020, 259. [CrossRef]

52. Pradhan, N.; Singh, P.; Dwivedi, P.; Pandey, D.K. Evaluation of sodium nitroprusside and putrescine on polyethylene glycol induced drought stress in Stevia rebaudiana Bertoni under in vitro condition. Ind. Crops Prod. 2020, 154, 112754. [CrossRef]

53. Sahay, S.; Khan, E.; Gupta, M. Nitric oxide and abscisic acid protects against PEG-induced drought stress differentially in Brassica genotypes by combining the role of stress modulators, markers and antioxidants. Nitric Oxide Biol. Chem. 2019, 89, 81-92. [CrossRef] [PubMed]

54. Verma, G.; Srivastava, D.; Tiwari, P.; Chakrabarty, D. ROS modulation in crop plants under drought stress. React. Oxyg. Nitrogen Sulfur Species Plants 2019, 311-336. [CrossRef]

55. Rezayian, M.; Ebrahimzadeh, H.; Niknam, V. Nitric oxide stimulates antioxidant system and osmotic adjustment in soybean under drought stress. J. Soil Sci. Plant Nutr. 2020, 20, 1122-1132. [CrossRef]

56. Sahay, S.; De La Cruz Torres, E.; Robledo-Arratia, L.; Gupta, M. Photosynthetic activity and RAPD profile of polyethylene glycol treated B. juncea L. under nitric oxide and abscisic acid application. J. Biotechnol. 2020, 313, 29-38. [CrossRef] 
57. Du, H.; Huang, F.; Wu, N.; Li, X.; Hu, H.; Xiong, L. Integrative regulation of drought escape through aba-dependent and -independent pathways in rice. Mol. Plant 2018, 11, 584-597. [CrossRef]

58. Li, L.; Wei, S.; Shen, W. The role of methane in plant physiology: A review. Plant Cell Rep. 2020, 39, 171-179. [CrossRef]

59. Yoshida, T.; Mogami, J.; Yamaguchi-Shinozaki, K. ABA-dependent and ABA-independent signaling in response to osmotic stress in plants. Curr. Opin. Plant Biol. 2014, 21, 133-139. [CrossRef]

60. Chen, Y.; Li, C.; Yi, J.; Yang, Y.; Lei, C.; Gong, M. Transcriptome response to drought, rehydration and re-dehydration in potato. Int. J. Mol. Sci. 2020, 21, 159. [CrossRef] [PubMed]

61. Arasimowicz-Jelonek, M.; Floryszak-Wieczorek, J.; Kubiś, J. Involvement of nitric oxide in water stress-induced responses of cucumber roots. Plant Sci. 2009, 177, 682-690. [CrossRef]

62. García-Mata, C.; Lamattina, L. Hydrogen sulphide, a novel gasotransmitter involved in guard cell signalling. New Phytol. 2010, 188, 977-984. [CrossRef]

63. Fu, Z.W.; Wang, Y.L.; Lu, Y.T.; Yuan, T.T. Nitric oxide is involved in stomatal development by modulating the expression of stomatal regulator genes in Arabidopsis. Plant Sci. 2016, 252, 282-289. [CrossRef] [PubMed]

64. Zhang, L.; Li, X.; Li, X.; Wei, Z.; Han, M.; Zhang, L.; Li, B. Exogenous nitric oxide protects against drought-induced oxidative stress in Malus rootstocks. Turk. J. Bot. 2016, 40, 17-27. [CrossRef]

65. Amnan, M.A.M.; Pua, T.L.; Lau, S.E.; Tan, B.C.; Yamaguchi, H.; Hitachi, K.; Tsuchida, K.; Komatsu, S. Osmotic stress in banana is relieved by exogenous nitric oxide. PeerJ 2021, 9, e10879. [CrossRef]

66. Akram, N.A.; Iqbal, M.; Muhammad, A.; Ashraf, M.; Al-Qurainy, F.; Shafiq, S. Aminolevulinic acid and nitric oxide regulate oxidative defense and secondary metabolisms in canola (Brassica napus L.) under drought stress. Protoplasma 2018, 255, 163-174. [CrossRef]

67. Batista, P.F.; Costa, A.C.; Müller, C.; de Oliveira Silva-Filho, R.; da Silva, F.B.; Merchant, A.; Mendes, G.C.; Nascimento, K.J.T. Nitric oxide mitigates the effect of water deficit in Crambe abyssinica. Plant Physiol. Biochem. 2018, 129, 310-322. [CrossRef]

68. Niu, L.; Yu, J.; Liao, W.; Yu, J.; Zhang, M.; Dawuda, M.M. Calcium and calmodulin are involved in nitric oxide-induced adventitious rooting of cucumber under simulated osmotic stress. Front. Plant Sci. 2017, 8, 1684. [CrossRef]

69. Jday, A.; Ben Rejeb, K.; Slama, I.; Saadallah, K.; Bordenave, M.; Planchais, S.; Savouré, A.; Abdelly, C. Effects of exogenous nitric oxide on growth, proline accumulation and antioxidant capacity in Cakile maritima seedlings subjected to water deficit stress. Funct. Plant Biol. 2016, 43, 939-948. [CrossRef] [PubMed]

70. Farouk, S.; Al-Huqail, A.A. Sodium nitroprusside application regulates antioxidant capacity, improves phytopharmaceutical production and essential oil yield of marjoram herb under drought. Ind. Crops Prod. 2020, 158, 113034. [CrossRef]

71. Zangani, E.; Zehtab-Salmasi, S.; Andalibi, B.; Zamani, A.A. Protective effects of nitric oxide on photosynthetic stability and performance of Silybum marianum under water deficit conditions. Agron. J. 2018, 110, 555-564. [CrossRef]

72. Rigui, A.P.; Carvalho, V.; Wendt dos Santos, A.L.; Morvan-Bertrand, A.; Prud'homme, M.P.; Machado de Carvalho, M.A.; Gaspar, M. Fructan and antioxidant metabolisms in plants of Lolium perenne under drought are modulated by exogenous nitric oxide. Plant Physiol. Biochem. 2019, 145, 205-215. [CrossRef] [PubMed]

73. Ghassemi-Golezani, K.; Farhadi, N.; Nikpour-Rashidabad, N. Responses of in vitro-cultured Allium hirtifolium to exogenous sodium nitroprusside under PEG-imposed drought stress. Plant Cell. Tissue Organ Cult. 2018, 133, 237-248. [CrossRef]

74. Hasanuzzaman, M.; Nahar, K.; Hossain, M.S.; Anee, T.I.; Parvin, K.; Fujita, M. Nitric oxide pretreatment enhances antioxidant defense and glyoxalase systems to confer peg-induced oxidative stress in rapeseed. J. Plant Interact. 2017, 12, 323-331. [CrossRef]

75. Wang, X.; Ruan, M.; Wan, Q.; He, W.; Yang, L.; Liu, X.; He, L.; Yan, L.; Bi, Y. Nitric oxide and hydrogen peroxide increase glucose-6-phosphate dehydrogenase activities and expression upon drought stress in soybean roots. Plant Cell Rep. 2020, 39, 63-73. [CrossRef] [PubMed]

76. Silveira, N.M.; Frungillo, L.; Marcos, F.C.C.; Pelegrino, M.T.; Miranda, M.T.; Seabra, A.B.; Salgado, I.; Machado, E.C.; Ribeiro, R.V. Exogenous nitric oxide improves sugarcane growth and photosynthesis under water deficit. Planta 2016, 244, 181-190. [CrossRef]

77. Mohasseli, V.; Sadeghi, S. Exogenously applied sodium nitroprusside improves physiological attributes and essential oil yield of two drought susceptible and resistant specie of Thymus under reduced irrigation. Ind. Crops Prod. 2019, 130, 130-136. [CrossRef]

78. Jangid, K.K.; Dwivedi, P. Physiological and biochemical changes by nitric oxide and brassinosteroid in tomato (Lycopersicon esculentum Mill.) under drought stress. Acta Physiol. Plant. 2017, 39. [CrossRef]

79. Hamurcu, M.; Khan, M.K.; Pandey, A.; Ozdemir, C.; Avsaroglu, Z.Z.; Elbasan, F.; Omay, A.H.; Gezgin, S. Nitric oxide regulates watermelon (Citrullus lanatus) responses to drought stress. 3 Biotech 2020, 10, 494. [CrossRef]

80. Hasanuzzaman, M.; Nahar, K.; Rahman, A.; Inafuku, M.; Oku, H.; Fujita, M. Exogenous nitric oxide donor and arginine provide protection against short-term drought stress in wheat seedlings. Physiol. Mol. Biol. Plants 2018, 24, 993-1004. [CrossRef]

81. Wu, S.; Sun, X.; Tan, Q.; Hu, C. Molybdenum improves water uptake via extensive root morphology, aquaporin expressions and increased ionic concentrations in wheat under drought stress. Environ. Exp. Bot. 2019, 157, 241-249. [CrossRef]

82. Farooq, M.; Nawaz, A.; Chaudhary, M.A.M.; Rehman, A. Foliage-applied sodium nitroprusside and hydrogen peroxide improves resistance against terminal drought in bread wheat. J. Agron. Crop Sci. 2017, 203, 473-482. [CrossRef]

83. Wang, H.; Huang, J.; Li, Y.; Li, C.; Hou, J.; Liang, W. Involvement of nitric oxide-mediated alternative pathway in tolerance of wheat to drought stress by optimizing photosynthesis. Plant Cell Rep. 2016, 35, 2033-2044. [CrossRef] [PubMed]

84. Li, Z.; Yong, B.; Cheng, B.; Wu, X.; Zhang, Y.; Zhang, X.; Peng, Y. Nitric oxide, $\gamma$-aminobutyric acid, and mannose pretreatment influence metabolic profiles in white clover under water stress. J. Integr. Plant Biol. 2019, 61, 1255-1273. [CrossRef] [PubMed] 
85. Shi, H.; Ye, T.; Zhu, J.K.; Chan, Z. Constitutive production of nitric oxide leads to enhanced drought stress resistance and extensive transcriptional reprogramming in Arabidopsis. J. Exp. Bot. 2014, 65, 4119-4131. [CrossRef]

86. Ahmad, M.A.; Gaur, R.; Gupta, M. Comparative biochemical and RAPD analysis in two varieties of rice (Oryza sativa) under arsenic stress by using various biomarkers. J. Hazard. Mater. 2012, 217-218, 141-148. [CrossRef]

87. Pandey, C.; Gupta, M. Selenium and auxin mitigates arsenic stress in rice (Oryza sativa L.) by combining the role of stress indicators, modulators and genotoxicity assay. J. Hazard. Mater. 2015, 287, 384-391. [CrossRef] [PubMed]

88. Gan, L.; Wu, X.; Zhong, Y. Exogenously applied nitric oxide enhances the drought tolerance in hulless barley. Plant Prod. Sci. 2015, 18, 52-56. [CrossRef]

89. Cai, W.; Liu, W.; Wang, W.S.; Fu, Z.W.; Han, T.T.; Lu, Y.T. Overexpression of rat neurons nitric oxide synthase in rice enhances drought and salt tolerance. PLoS ONE 2015, 10, e0131599. [CrossRef] [PubMed]

90. Qian, B.; Li, X.; Liu, X.; Chen, P.; Ren, C.; Dai, C. Enhanced drought tolerance in transgenic rice over-expressing of maize C4 phosphoenolpyruvate carboxylase gene via $\mathrm{NO}$ and $\mathrm{Ca}^{2+}$. J. Plant Physiol. 2015, 175, 9-20. [CrossRef] [PubMed]

91. Wu, H.; Zheng, Y.; Liu, J.; Zhang, H.; Chen, H. Heme oxygenase-1 delays gibberellin-induced programmed cell death of rice aleurone layers subjected to drought stress by interacting with nitric oxide. Front. Plant Sci. 2016, 6, 1-13. [CrossRef]

92. Rodríguez-Serrano, M.; Bárány, I.; Prem, D.; Coronado, M.J.; Risueño, M.C.; Testillano, P.S. NO, ROS, and cell death associated with caspase-like activity increase in stress-induced microspore embryogenesis of barley. J. Exp. Bot. 2012, 63, $2007-2024$. [CrossRef] [PubMed]

93. Jiang, X.; Ren, R.; Di, W.; Jia, M.; Li, Z.; Liu, Y.; Gao, R. Hydrogen peroxide and nitric oxide are involved in programmed cell death induced by cryopreservation in Dendrobium protocorm-like bodies. Plant Cell Tissue Organ Cult. 2019, 137, 553-563. [CrossRef]

94. Hasanuzzaman, M.; Bhuyan, M.H.M.B.; Parvin, K.; Bhuiyan, T.F.; Anee, T.I.; Nahar, K.; Hossen, M.S.; Zulfiqar, F.; Alam, M.M.; Fujita, M. Regulation of ros metabolism in plants under environmental stress: A review of recent experimental evidence. Int. J. Mol. Sci. 2020, 21, 8695. [CrossRef]

95. Huang, D.; Huo, J.; Liao, W. Hydrogen sulfide: Roles in plant abiotic stress response and crosstalk with other signals. Plant Sci. 2021, 302, 110733. [CrossRef]

96. Aroca, A.; Benito, J.M.; Gotor, C.; Romero, L.C. Persulfidation proteome reveals the regulation of protein function by hydrogen sulfide in diverse biological processes in Arabidopsis. J. Exp. Bot. 2017, 68, 4915-4927. [CrossRef]

97. Khan, M.N.; Mobin, M.; Abbas, Z.K.; Siddiqui, M.H. Nitric oxide-induced synthesis of hydrogen sulfide alleviates osmotic stress in wheat seedlings through sustaining antioxidant enzymes, osmolyte accumulation and cysteine homeostasis. Nitric Oxide Biol. Chem. 2017, 68, 91-102. [CrossRef] [PubMed]

98. Shi, C.; Qi, C.; Ren, H.; Huang, A.; Hei, S.; She, X. Ethylene mediates brassinosteroid-induced stomatal closure via G $\alpha$ proteinactivated hydrogen peroxide and nitric oxide production in Arabidopsis. Plant J. 2015, 82, 280-301. [CrossRef]

99. Wang, X.; Li, Q.; Yang, M.; Zhang, J.; Huang, M.; Cai, J.; Zhou, Q.; Dai, T.; Wollenweber, B.; Jiang, D. Crosstalk between hydrogen peroxide and nitric oxide mediates priming-induced drought tolerance in wheat. J. Agron. Crop Sci. 2020, in press. [CrossRef]

100. Bright, J.; Desikan, R.; Hancock, J.T.; Weir, I.S.; Neill, S.J. ABA-induced NO generation and stomatal closure in Arabidopsis are dependent on $\mathrm{H}_{2} \mathrm{O}_{2}$ synthesis. Plant J. 2006, 45, 113-122. [CrossRef] [PubMed]

101. Liao, W.B.; Huang, G.B.; Yu, J.H.; Zhang, M.L. Nitric oxide and hydrogen peroxide alleviate drought stress in marigold explants and promote its adventitious root development. Plant Physiol. Biochem. 2012, 58, 6-15. [CrossRef] [PubMed]

102. Liao, W.-B.; Zhang, M.-L.; Huang, G.-B.; Yu, J.-H. Ca ${ }^{2+}$ and CaM are involved in NO- and $\mathrm{H}_{2} \mathrm{O}_{2}$-induced adventitious root development in marigold. J. Plant Growth Regul. 2012, 31, 253-264. [CrossRef]

103. Lamotte, O.; Gould, K.; Lecourieux, D.; Sequeira-Legrand, A.; Lebrun-Garcia, A.; Durner, J.; Pugin, A.; Wendehenne, D. Analysis of nitric oxide signaling functions in tobacco cells challenged by the elicitor cryptogein. Plant Physiol. 2004, 135, 516-529. [CrossRef]

104. Lamotte, O.; Courtois, C.; Dobrowolska, G.; Besson, A.; Pugin, A.; Wendehenne, D. Mechanisms of nitric-oxide-induced increase of free cytosolic $\mathrm{Ca}^{2+}$ concentration in Nicotiana plumbaginifolia cells. Free Radic. Biol. Med. 2006, 40, 1369-1376. [CrossRef]

105. Rodríguez-Serrano, M.; Romero-Puertas, M.C.; Pazmino, D.M.; Testillano, P.S.; Risueno, M.C.; Del Río, L.A.; Sandalio, L.M. Cellular response of pea plants to cadmium toxicity: Cross talk between reactive oxygen species, nitric oxide, and calcium. Plant Physiol. 2009, 150, 229-243. [CrossRef]

106. Zou, J.J.; Wei, F.J.; Wang, C.; Wu, J.J.; Ratnasekera, D.; Liu, W.X.; Wu, W.H. Arabidopsis calcium-dependent protein kinase cpk10 functions in abscisic acid- and $\mathrm{Ca}^{2+}$-mediated stomatal regulation in response to drought stress. Plant Physiol. 2010, 154, 1232-1243. [CrossRef] [PubMed]

107. Foresi, N.; Mayta, M.L.; Lodeyro, A.F.; Scuffi, D.; Correa-Aragunde, N.; García-Mata, C.; Casalongué, C.; Carrillo, N.; Lamattina, L. Expression of the tetrahydrofolate-dependent nitric oxide synthase from the green alga Ostreococcus tauri increases tolerance to abiotic stresses and influences stomatal development in Arabidopsis. Plant J. 2015, 82, 806-821. [CrossRef] [PubMed]

108. Tan, D.-X.; Reiter, R.J. Mitochondria: The birth place, battle ground and the site of melatonin metabolism in cells. Melatonin Res. 2019, 2, 44-66. [CrossRef]

109. Liang, B.; Ma, C.; Zhang, Z.; Wei, Z.; Gao, T.; Zhao, Q.; Ma, F.; Li, C. Long-term exogenous application of melatonin improves nutrient uptake fluxes in apple plants under moderate drought stress. Environ. Exp. Bot. 2018, 155, 650-661. [CrossRef] 
110. Antoniou, C.; Chatzimichail, G.; Xenofontos, R.; Pavlou, J.J.; Panagiotou, E.; Christou, A.; Fotopoulos, V. Melatonin systemically ameliorates drought stress-induced damage in Medicago sativa plants by modulating nitro-oxidative homeostasis and proline metabolism. J. Pineal Res. 2017, 62, e12401. [CrossRef]

111. Shi, H.T.; Li, R.J.; Cai, W.; Liu, W.; Wang, C.L.; Lu, Y.T. Increasing nitric oxide content in Arabidopsis thaliana by expressing rat neuronal nitric oxide synthase resulted in enhanced stress tolerance. Plant Cell Physiol. 2012, 53, 344-357. [CrossRef]

112. He, H.; He, L.-F. Crosstalk between melatonin and nitric oxide in plant development and stress responses. Physiol. Plant. 2020, 170, 218-226. [CrossRef]

113. Arese, M.; Magnifico, M.C.; Mastronicola, D.; Altieri, F.; Grillo, C.; Blanck, T.J.J.; Sarti, P. Nanomolar melatonin enhances nNOS expression and controls HaCaT-cells bioenergetics. IUBMB Life 2012, 64, 251-258. [CrossRef]

114. Sarti, P.; Forte, E.; Giuffrè, A.; Mastronicola, D.; Magnifico, M.C.; Arese, M. The chemical interplay between nitric oxide and mitochondrial cytochrome c oxidase: Reactions, effectors and pathophysiology. Int. J. Cell Biol. 2012, 2012. [CrossRef]

115. Zhang, L.; Shi, X.; Zhang, Y.; Wang, J.; Yang, J.; Ishida, T.; Jiang, W.; Han, X.; Kang, J.; Wang, X.; et al. CLE9 peptide-induced stomatal closure is mediated by abscisic acid, hydrogen peroxide, and nitric oxide in Arabidopsis thaliana. Plant Cell Environ. 2019, 42, 1033-1044. [CrossRef] [PubMed]

116. Diao, Q.; Song, Y.; Shi, D.; Qi, H. Interaction of polyamines, abscisic acid, nitric oxide, and hydrogen peroxide under chilling stress in tomato (Lycopersicon esculentum mill.) seedlings. Front. Plant Sci. 2017, 8, 203. [CrossRef]

117. Alcázar, R.; Altabella, T.; Marco, F.; Bortolotti, C.; Reymond, M.; Koncz, C.; Carrasco, P.; Tiburcio, A.F. Polyamines: Molecules with regulatory functions in plant abiotic stress tolerance. Planta 2010, 231, 1237-1249. [CrossRef]

118. Hussain, S.S.; Ali, M.; Ahmad, M.; Siddique, K.H.M. Polyamines: Natural and engineered abiotic and biotic stress tolerance in plants. Biotechnol. Adv. 2011, 29, 300-311. [CrossRef]

119. Yang, B.; Wu, J.; Gao, F.; Wang, J.; Su, G. Polyamine-induced nitric oxide generation and its potential requirement for peroxide in suspension cells of soybean cotyledon node callus. Plant Physiol. Biochem. 2014, 79, 41-47. [CrossRef] [PubMed]

120. Tun, N.N.; Santa-Catarina, C.; Begum, T.; Silveira, V.; Handro, W.; Segal Floh, E.I.; Scherer, G.F.E. Polyamines induce rapid biosynthesis of nitric oxide (NO) in Arabidopsis thaliana seedlings. Plant Cell Physiol. 2006, 47, 346-354. [CrossRef]

121. Arasimowicz-Jelonek, M.; Floryszak-Wieczorek, J.; Kubiś, J. Interaction between polyamine and nitric oxide signaling in adaptive responses to drought in cucumber. J. Plant Growth Regul. 2009, 28, 177-186. [CrossRef]

122. Montilla-Bascón, G.; Rubiales, D.; Hebelstrup, K.H.; Mandon, J.; Harren, F.J.M.; Cristescu, S.M.; Mur, L.A.J.; Prats, E. Reduced nitric oxide levels during drought stress promote drought tolerance in barley and is associated with elevated polyamine biosynthesis. Sci. Rep. 2017, 7, 13311. [CrossRef] [PubMed]

123. Prakash, V.; Singh, V.P.; Tripathi, D.K.; Sharma, S.; Corpas, F.J. Crosstalk between nitric oxide (NO) and abscisic acid (ABA) signalling molecules in higher plants. Environ. Exp. Bot. 2019, 161, 41-49. [CrossRef]

124. Zhang, J.; Jia, W.; Yang, J.; Ismail, A.M. Role of ABA in integrating plant responses to drought and salt stresses. Field Crop. Res. 2006, 97, 111-119. [CrossRef]

125. Freschi, L. Nitric oxide and phytohormone interactions: Current status and perspectives. Front. Plant Sci. 2013, 4, 398. [CrossRef]

126. Liu, Y.-c.; Ma, W.; Niu, J.-f.; Li, B.; Zhou, W.; Liu, S.; Yan, Y.-p.; Ma, J.; Wang, Z. zhi Systematic analysis of SmWD40s, and responding of SmWD40-170 to drought stress by regulation of ABA- and $\mathrm{H}_{2} \mathrm{O}_{2}$-induced stomal movement in Salvia miltiorrhiza bunge. Plant Physiol. Biochem. 2020, 153, 131-140. [CrossRef] [PubMed]

127. Desikan, R.; Griffiths, R.; Hancock, J.; Neill, S. A new role for an old enzyme: Nitrate reductase-mediated nitric oxide generation is required for abscisic acid-induced stomatal closure in Arabidopsis thaliana. Proc. Natl. Acad. Sci. USA 2002, 99, 16314-16318. [CrossRef] [PubMed]

128. Dubovskaya, L.V.; Bakakina, Y.S.; Kolesneva, E.V.; Sodel, D.L.; Mcainsh, M.R.; Hetherington, A.M.; Volotovski, I.D. cGMPdependent ABA-induced stomatal closure in the ABA-insensitive Arabidopsis mutant abi1-1. New Phytol. 2011, 191, 57-69. [CrossRef]

129. Wang, P.; Du, Y.; Hou, Y.J.; Zhao, Y.; Hsu, C.C.; Yuan, F.; Zhu, X.; Tao, W.A.; Song, C.P.; Zhu, J.K. Nitric oxide negatively regulates abscisic acid signaling in guard cells by S-nitrosylation of OST1. Proc. Natl. Acad. Sci. USA 2015, 112, 613-618. [CrossRef]

130. Khan, M.; Imran, Q.M.; Shahid, M.; Mun, B.G.; Lee, S.U.; Khan, M.A.; Hussain, A.; Lee, I.J.; Yun, B.W. Nitric oxide- induced AtAO3 differentially regulates plant defense and drought tolerance in Arabidopsis thaliana. BMC Plant Biol. 2019, 19, 602. [CrossRef] [PubMed]

131. Ren, X.; Chen, Z.; Liu, Y.; Zhang, H.; Zhang, M.; Liu, Q.; Hong, X.; Zhu, J.K.; Gong, Z. ABO 3, a WRKY transcription factor, mediates plant responses to abscisic acid and drought tolerance in Arabidopsis. Plant J. 2010, 63, 417-429. [CrossRef] [PubMed]

132. Imran, Q.M.; Hussain, A.; Mun, B.G.; Lee, S.U.; Asaf, S.; Ali, M.A.; Lee, I.J.; Yun, B.W. Transcriptome wide identification and characterization of NO-responsive WRKY transcription factors in Arabidopsis thaliana L. Environ. Exp. Bot. 2018, 148, 128-143. [CrossRef]

133. Dar, T.A.; Uddin, M.; Khan, M.M.A.; Hakeem, K.R.; Jaleel, H. Jasmonates counter plant stress: A review. Environ. Exp. Bot. 2015, 115, 49-57. [CrossRef]

134. Liu, X.; Shi, W.; Zhang, S.; Lou, C. Nitric oxide involved in signal transduction of Jasmonic acid-induced stomatal closure of Vicia faba L. Chinese Sci. Bull. 2005, 50, 520-525. [CrossRef]

135. Palmieri, M.C.; Sell, S.; Huang, X.; Scherf, M.; Werner, T.; Durner, J.; Lindermayr, C. Nitric oxide-responsive genes and promoters in Arabidopsis thaliana: A bioinformatics approach. J. Exp. Bot. 2008, 59, 177-186. [CrossRef] [PubMed] 
136. Jian, W.W.; Wu, J.Y. Nitric oxide is involved in methyl jasmonate-induced defense responses and secondary metabolism activities of Taxus cells. Plant Cell Physiol. 2005, 46, 923-930. [CrossRef]

137. Shan, C.; Zhou, Y.; Liu, M. Nitric oxide participates in the regulation of the ascorbate-glutathione cycle by exogenous jasmonic acid in the leaves of wheat seedlings under drought stress. Protoplasma 2015, 252, 1397-1405. [CrossRef] [PubMed]

138. Zottini, M.; Costa, A.; De Michele, R.; Ruzzene, M.; Carimi, F.; Lo Schiavo, F. Salicylic acid activates nitric oxide synthesis in Arabidopsis. J. Exp. Bot. 2007, 58, 1397-1405. [CrossRef] [PubMed]

139. Asgher, M.; Per, T.S.; Masood, A.; Fatma, M.; Freschi, L.; Corpas, F.J.; Khan, N.A. Nitric oxide signaling and its crosstalk with other plant growth regulators in plant responses to abiotic stress. Environ. Sci. Pollut. Res. 2017, 24, 2273-2285. [CrossRef]

140. Gémes, K.; Poór, P.; Horváth, E.; Kolbert, Z.; Szopkó, D.; Szepesi, Á.; Tari, I. Cross-talk between salicylic acid and NaCl-generated reactive oxygen species and nitric oxide in tomato during acclimation to high salinity. Physiol. Plant. 2011, 142, 179-192. [CrossRef] [PubMed]

141. Hao, F.; Zhao, S.; Dong, H.; Zhang, H.; Sun, L.; Miao, C. Nia1 and Nia2 are involved in exogenous salicylic acid-induced nitric oxide generation and stomatal closure in Arabidopsis. J. Integr. Plant Biol. 2010, 52, 298-307. [CrossRef]

142. Fahad, S.; Hussain, S.; Matloob, A.; Khan, F.A.; Khaliq, A.; Saud, S.; Hassan, S.; Shan, D.; Khan, F.; Ullah, N.; et al. Phytohormones and plant responses to salinity stress: A review. Plant Growth Regul. 2015, 75, 391-404. [CrossRef]

143. Scherer, G.F.E.; Holk, A. NO donors mimic and NO inhibitors inhibit cytokinin action in betalaine accumulation in Amaranthus caudatus. Plant Growth Regul. 2000, 32, 345-350. [CrossRef]

144. Shao, R.; Wang, K.; Shangguan, Z. Cytokinin-induced photosynthetic adaptability of Zea mays L. to drought stress associated with nitric oxide signal: Probed by ESR spectroscopy and fast OJIP fluorescence rise. J. Plant Physiol. 2010, 167, 472-479. [CrossRef]

145. Shen, Q.; Wang, Y.T.; Tian, H.; Guo, F.Q. Nitric oxide mediates cytokinin functions in cell proliferation and meristem maintenance in Arabidopsis. Mol. Plant 2013, 6, 1214-1225. [CrossRef] [PubMed]

146. Xiao-Ping, S.; Xi-Gui, S. Cytokinin- and auxin-induced stomatal opening is related to the change of nitric oxide levels in guard cells in broad bean. Physiol. Plant. 2006, 128, 569-579. [CrossRef]

147. Kong, X.; Wang, T.; Li, W.; Tang, W.; Zhang, D.; Dong, H. Exogenous nitric oxide delays salt-induced leaf senescence in cotton (Gossypium hirsutum L.). Acta Physiol. Plant. 2016, 38, 61. [CrossRef]

148. Mengel, A.; Chaki, M.; Shekariesfahlan, A.; Lindermayr, C. Effect of nitric oxide on gene transcription-S-nitrosylation of nuclear proteins. Front. Plant Sci. 2013, 4, 1-7. [CrossRef]

149. Whiteman, M.; Li, L.; Kostetski, I.; Chu, S.H.; Siau, J.L.; Bhatia, M.; Moore, P.K. Evidence for the formation of a novel nitrosothiol from the gaseous mediators nitric oxide and hydrogen sulphide. Biochem. Biophys. Res. Commun. 2006, 343, 303-310. [CrossRef] [PubMed]

150. Belenghi, B.; Romero-Puertas, M.C.; Vercammen, D.; Brackenier, A.; Inzé, D.; Delledonne, M.; Van Breusegem, F. Metacaspase activity of Arabidopsis thaliana is regulated by S-nitrosylation of a critical cysteine residue. J. Biol. Chem. 2007, 282, 1352-1358. [CrossRef]

151. Ortega-Galisteo, A.P.; Rodríguez-Serrano, M.; Pazmiño, D.M.; Gupta, D.K.; Sandalio, L.M.; Romero-Puertas, M.C. S-Nitrosylated proteins in pea (Pisum sativum L.) leaf peroxisomes: Changes under abiotic stress. J. Exp. Bot. 2012, 63, 2089-2103. [CrossRef]

152. Feechan, A.; Kwon, E.; Yun, B.W.; Wang, Y.; Pallas, J.A.; Loake, G.J. A central role for S-nitrosothiols in plant disease resistance. Proc. Natl. Acad. Sci. USA 2005, 102, 8054-8059. [CrossRef]

153. Wang, P.; Zhu, J.K.; Lang, Z. Nitric oxide suppresses the inhibitory effect of abscisic acid on seed germination by S-nitrosylation of SnRK2 proteins. Plant Signal. Behav. 2015, 10, 2-5. [CrossRef]

154. Correa-Aragunde, N.; Foresi, N.; Delledonne, M.; Lamattina, L. Auxin induces redox regulation of ascorbate peroxidase 1 activity by S-nitrosylation/denitrosylation balance resulting in changes of root growth pattern in Arabidopsis. J. Exp. Bot. 2013, 64, 3339-3349. [CrossRef]

155. Feng, J.; Wang, C.; Chen, Q.; Chen, H.; Ren, B.; Li, X.; Zuo, J. S-nitrosylation of phosphotransfer proteins represses cytokinin signaling. Nat. Commun. 2013, 4. [CrossRef]

156. Begara-Morales, J.C.; Sánchez-Calvo, B.; Chaki, M.; Valderrama, R.; Mata-Pérez, C.; Padilla, M.N.; Corpas, F.J.; Barroso, J.B. Antioxidant systems are regulated by nitric oxide-mediated post-translational modifications (NO-PTMs). Front. Plant Sci. 2016, 7 , 152. [CrossRef] [PubMed]

157. Chaki, M.; Valderrama, R.; Fernández-Ocaña, A.M.; Carreras, A.; Gómez-Rodríguez, M.V.; López-Jaramillo, J.; Begara-Morales, J.C.; Sánchez-Calvo, B.; Luque, F.; Leterrier, M.; et al. High temperature triggers the metabolism of S-nitrosothiols in sunflower mediating a process of nitrosative stress which provokes the inhibition of ferredoxin-NADP reductase by tyrosine nitration. Plant Cell Environ. 2011, 34, 1803-1818. [CrossRef] [PubMed]

158. Chaki, M.; Valderrama, R.; Fernández-Ocaña, A.M.; Carreras, A.; Gómez-Rodríguez, M.V.; Pedrajas, J.R.; Begara-Morales, J.C.; Sánchez-Calvo, B.; Luque, F.; Leterrier, M.; et al. Mechanical wounding induces a nitrosative stress by down-regulation of GSNO reductase and an increase in S-nitrosothiols in sunflower (Helianthus annuus) seedlings. J. Exp. Bot. 2011, 62, 1803-1813. [CrossRef] [PubMed]

159. Yun, B.W.; Feechan, A.; Yin, M.; Saidi, N.B.B.; Le Bihan, T.; Yu, M.; Moore, J.W.; Kang, J.G.; Kwon, E.; Spoel, S.H.; et al. S-nitrosylation of NADPH oxidase regulates cell death in plant immunity. Nature 2011, 478, 264-268. [CrossRef]

160. Feng, J.; Chen, L.; Zuo, J. Protein S-Nitrosylation in plants: Current progresses and challenges. J. Integr. Plant Biol. 2019, 61, 1206-1223. [CrossRef] 
161. Vandelle, E.; Delledonne, M. Peroxynitrite formation and function in plants. Plant Sci. 2011, 181, 534-539. [CrossRef]

162. Holzmeister, C.; Gaupels, F.; Geerlof, A.; Sarioglu, H.; Sattler, M.; Durner, J.; Lindermayr, C. Differential inhibition of Arabidopsis superoxide dismutases by peroxynitrite-mediated tyrosine nitration. J. Exp. Bot. 2015, 66, 989-999. [CrossRef]

163. Castillo, M.-C.; Lozano-Juste, J.; González-Guzmán, M.; Rodriguez, L.; Rodriguez, P.L.; León, J. Inactivation of PYR/PYL/RCAR ABA receptors by tyrosine nitration may enable rapid inhibition of ABA signaling by nitric oxide in plants. Sci. Signal. 2015, 8 , ra89. [CrossRef]

164. Zhang, S.; Melzer, M.M.; Sen, S.N.; Çelebi-Ölçüm, N.; Warren, T.H. A motif for reversible nitric oxide interactions in metalloenzymes. Nat. Chem. 2016, 8, 663-669. [CrossRef]

165. Hebelstrup, K.H.; van Zanten, M.; Mandon, J.; Voesenek, L.A.C.J.; Harren, F.J.M.; Cristescu, S.M.; Møller, I.M.; Mur, L.A.J. Haemoglobin modulates NO emission and hyponasty under hypoxia-related stress in Arabidopsis thaliana. J. Exp. Bot. 2012, 63, 5581-5591. [CrossRef] [PubMed]

166. Zaffagnini, M.; De Mia, M.; Morisse, S.; Di Giacinto, N.; Marchand, C.H.; Maes, A.; Lemaire, S.D.; Trost, P. Protein S-nitrosylation in photosynthetic organisms: A comprehensive overview with future perspectives. Biochim. Biophys. Acta Proteins Proteom. 2016, 1864, 952-966. [CrossRef] [PubMed]

167. Griveau, S.; Besson-Bard, A.; Bedioui, F.; Wendehenne, D. Electrochemical Detection of Nitric Oxide in Plant Cell Suspensions. In Plant Nitric Oxide: Methods and Protocols, 1st ed.; Gupta, K.J., Ed.; Springer: New York, NY, USA, 2016; pp. 127-137.

168. Mur, L.A.J.; Mandon, J.; Cristescu, S.M.; Harren, F.J.M.; Prats, E. Methods of nitric oxide detection in plants: A commentary. Plant Sci. 2011, 181, 509-519. [CrossRef]

169. Ruemer, S.; Krischke, M.; Fekete, A.; Lesch, M.; Mueller, M.J.; Kaiser, W.M. Methods to Detect Nitric Oxide in Plants: Are DAFs Really Measuring NO? In Plant Nitric Oxide: Methods and Protocols, 1st ed.; Gupta, K.J., Ed.; Springer: New York, NY, USA, 2016; pp. 57-68.

170. Planchet, E.; Kaiser, W.M. Nitric oxide (NO) detection by DAF fluorescence and chemiluminescence: A comparison using abiotic and biotic NO sources. J. Exp. Bot. 2006, 57, 3043-3055. [CrossRef] [PubMed]

171. Wany, A.; Gupta, K.J. Localization of Nitric Oxide in Wheat Roots by DAF Fluorescence. In Plant Nitric Oxide: Methods and Protocols, 1st ed.; Gupta, K.J., Ed.; Springer: New York, NY, USA, 2016; pp. 39-47.

172. Ren, Q.Q.; Huang, X.R.; Liu, G.C.; Jun, O.Y.; Li, M.T.; Chen, H.; Zhao, Y.-D.; Chen, W. A field-compatible technique using an electrochemical sensing microbundle for real-time and simultaneous in vivo measurement of hydrogen peroxide, nitric oxide, and $\mathrm{pH}$ under drought stress. Sens. Actuators B Chem. 2015, 220, 743-748. [CrossRef]

173. Makishima, A. Topics of Bioluminescence and Chemoluminescence. In Biochemistry for Materials Science: Catalysis, Complexes and Proteins, 1st ed.; Gifford, C., Ed.; Elsevier: Amsterdam, The Netherlands, 2019; Volume 1, pp. 77-83.

174. Hetrick, E.M.; Schoenfisch, M.H. Analytical chemistry of nitric oxide. Annu. Rev. Anal. Chem. 2009, 2, 409-433. [CrossRef]

175. Davies, M.J. Detection and characterisation of radicals using electron paramagnetic resonance (EPR) spin trapping and related methods. Methods 2016, 109, 21-30. [CrossRef]

176. Csonka, C.; Páli, T.; Bencsik, P.; Görbe, A.; Ferdinandy, P.; Csont, T. Measurement of NO in biological samples. Br. J. Pharmacol. 2015, 172, 1620-1632. [CrossRef]

177. Kohno, M. Applications of electron spin resonance spectrometry for reactive oxygen species and reactive nitrogen species research. J. Clin. Biochem. Nutr. 2010, 47, 1-11. [CrossRef]

178. Griendling, K.K.; Touyz, R.M.; Zweier, J.L.; Dikalov, S.; Chilian, W.; Chen, Y.R.; Harrison, D.G.; Bhatnagar, A. Measurement of reactive oxygen species, reactive nitrogen species, and redox-dependent signaling in the cardiovascular system: A scientific statement from the American heart association. Circ. Res. 2016, 119, e39-e75. [CrossRef] [PubMed]

179. Bright, J.; Hiscock, S.J.; James, P.E.; Hancock, J.T. Pollen generates nitric oxide and nitrite: A possible link to pollen-induced allergic responses. Plant Physiol. Biochem. 2009, 47, 49-55. [CrossRef] [PubMed]

180. Besson-Bard, A.; Griveau, S.; Bedioui, F.; Wendehenne, D. Real-time electrochemical detection of extracellular nitric oxide in tobacco cells exposed to cryptogein, an elicitor of defence responses. J. Exp. Bot. 2008, 59, 3407-3414. [CrossRef] [PubMed] 